Article

\title{
Design of Organoiron Dendrimers Containing Paracetamol for Enhanced Antibacterial Efficacy
}

\author{
Alaa S. Abd-El-Aziz *, Ebtehal G. El-Ghezlani and Amani A. Abdelghani \\ Department of Chemistry, University of Prince Edward Island, 550 University Avenue, \\ Charlottetown, PE C1A 4P3, Canada; eel@upei.ca (E.G.E.-G.); aabdelghani@upei.ca (A.A.A.) \\ * Correspondence: abdelaziz@upei.ca
}

Academic Editor: Kristof Van Hecke

Received: 8 September 2020; Accepted: 28 September 2020; Published: 2 October 2020

\begin{abstract}
Paracetamol (acetaminophen) is a common painkiller and antipyretic drug used globally. Attachment of paracetamol to a series of organoiron dendrimers was successfully synthesized. The aim of this study is to combine the benefits of the presence of these redox-active organoiron dendrimers, their antimicrobial activities against some human pathogenic Gram-positive, and the therapeutic characteristics of paracetamol. The antimicrobial activity of these dendrimers was investigated and tested with a minimum inhibitory concentration and this has been reported. Some of these newly synthesized dendrimers exhibited the highest inhibitory activity against methicillin-resistant Staphylococcus aureus (MRSA), vancomycin-resistant Enterococcus faecium (VRE), and Staphylococcus warneri compared to reference drugs. The results of this study indicate that the antimicrobial efficacy of the dendrimers is dependent on the size of the redox-active organoiron dendrimer and its terminal functionalities. The best result has been recorded for the fourth-generation dendrimer 11, which attached to 48 paracetamol end groups and has 90 units composed of the $\eta^{6}$-aryl- $\eta^{5}$-cyclopentadienyliron (II) complex. This dendrimer presented inhibition of $50 \%$ of the growth $\left(\mathrm{IC}_{50}\right)$ of $0.52 \mu \mathrm{M}$ for MRSA, $1.02 \mu \mathrm{M}$ for VRE, and $0.73 \mu \mathrm{M}$ for Staphylococcus warneri. The structures of the dendrimers were characterized by elemental analysis, Fourier transform infrared (FT-IR), nuclear magnetic resonance $\left({ }^{1} \mathrm{H}-\mathrm{NMR}\right)$, and ${ }^{13} \mathrm{C}-\mathrm{NMR}$ spectroscopic techniques. In addition, all synthesized dendrimers displayed good thermal stability in the range of $300-350{ }^{\circ} \mathrm{C}$ following the degradation of the cationic iron moieties which occurred around $200^{\circ} \mathrm{C}$.
\end{abstract}

Keywords: dendrimer; paracetamol; organoiron; redox-active; MRSA; VRE; staphylococcus warneri; SEM

\section{Introduction}

Multidrug-resistant diseases are a global burden with a continuous loss of human life predicted for the future [1]. While careful use of antimicrobials provides a possible solution, the development of novel types of antimicrobials with different mechanisms of action is important to help in the fight against the rise of multidrug-resistant infections such as methicillin-resistant Staphyloccus aureus (MRSA) and vancomycin-resistant Enterococcus faecium (VRE). As a result, synthesis and investigation of antimicrobial molecules and macromolecules has been given a great deal of interest [2-6]. Indeed, these macromolecules have been used for the treatment and inhibition of multidrug-resistant infections [2-6]. Dendrimers are the best class of these macromolecules as their structures can be intelligently designed to improve the activity and increase selectivity [6]. Dendrimers are unique highly branched 3-dimensional macromolecules that arise from a central core [7-10]. Several unique properties associated with dendrimers allows them to be used in many applications such as catalysis [11-14], sensing [15-17], and fluorescence applications [18-22], General synthesis routes to these dendrimers involve functionalizing the periphery with antimicrobial agents [6]. The search for unique synthesis approaches of antimicrobial dendrimers is expanding with the focus on enhanced activity upon resistant strains $[15,16,23-36]$. 
The advantage of including $\eta^{6}$-aryl- $\eta^{5}$-cyclopentadienyliron (II) complexes into dendritic structures is to provide highly-ordered structures with engaging bioactivity and other properties $[16,37,38]$. Doubtless, the association of organo-transition metal groups within dendritic structures has attracted attention in both organometallic and dendrimer research and opened up a new family of organometallic macromolecules with many novel properties [39-42]. The complex, as well as its dendrimer derivatives, were confirmed in our previous studies to display antimicrobial activity [33,43].

The first published use of paracetamol (N-acetyl-p-aminophenol, also commonly known as acetaminophen) for therapeutic purposes in humans was by Von Mering in 1893, but it was not generally used until the 1950s [44]. Now, paracetamol is the most important coal tar derivative analgesic drug, due to its minor toxicity which allows it to be used more widely. Despite the popularity of this drug, the mechanism by which paracetamol achieves its effects on fever and pain is still under discussion [45]. It could be through the activation of descending serotonergic pathways, due to the inhibition of prostaglandin (PG) synthesis, or through an active metabolite affecting cannabinoid receptors [45]. Due to the similarity between paracetamol and aspirin in analgesic and antipyretic non-steroidal anti-inflammatory drugs (NSAIDs), a great deal of research has centered on paracetamol inhibition of the Cyclooxygenase (COX) enzyme, however, paracetamol does not have significant anti-inflammatory activity [46].

While paracetamol does allow for a reduction of morphine use, thereby diminishing morphine-related opposing effects [47-50], the implicit principle is that the distinct modes of action of morphine and paracetamol provide maximum analgesia to be managed with a lower dose of morphine, and, consequently, a smaller percentage of morphine-related adverse effects occur [47-50].

In this work, we tested the antimicrobial activity of a series of cationic, redox-active dendrimers against microorganisms that included MRSA, VRE, and Staphylococcus warneri. The primary properties of macromolecules such as thermal stability using thermogravimetric analysis (TGA) and electrochemistry using cyclic voltammetry $(\mathrm{CV})$ were also investigated. The results show that the antimicrobial dendrimers generated free radicals, had good thermal stability, and exerted an excellent antimicrobial activity against multidrug-resistant bacteria. In addition, the dendrimeric structure was approved by spectroscopic and elemental analyses, which were also utilized to differentiate between the four generations of dendrimers as well as terminal end groups of the same generation. The determination of the morphology of dried residues of the dendrimers was also performed using scanning electron microscopy (SEM).

\section{Results and Discussion}

The purpose of this article was the design of an organometallic dendrimer with a painkiller and tunable antimicrobial activity. Four dendrimers were functionalized with paracetamol in the first, second, third, and fourth generations. To achieve this, the redox-active organoiron moieties were incorporated throughout every dendritic branch.

\subsection{Syntheses and Characterization of the Complexes}

All dendrimers were synthesized from cationic $\eta^{6}$-arene- $\eta^{5}$-cyclopentadienyliron(II) (Cp-Fe ${ }^{\mathrm{II}}$-arene) complexes of $\mathrm{PF}_{6}{ }^{-}$counteranions using a common synthetic route previously described here and presented in Schemes 1-4. The chemistry of the complex allows easy functionalization of the periphery of the dendrimers with the painkiller paracetamol, producing antimicrobial organometallic dendrimers with central analgesia properties. For example, the synthesis of the first-generation D1, second-generation D4, third-generation D7, and fourth-generation D10, involved esterification of the carboxylic groups of complex $\mathbf{1}$ with the hydroxy group, to form the first set of dendrimers with chloro end group. The nucleophilic substitution reaction of these dendrimers with paracetamol 2, leads to the second set of dendrimers, first-generation D2, second-generation D5, third-generation D8, and fourth-generation D11, with paracetamol end group. The last set of dendrimers were used 4-hydroxybenzyl alcohol 3 to form first-generation D3, second-generation D6, third-generation D9, 
and fourth-generation D12, with the hydroxyl end group, by the nucleophilic substitution reaction as well.

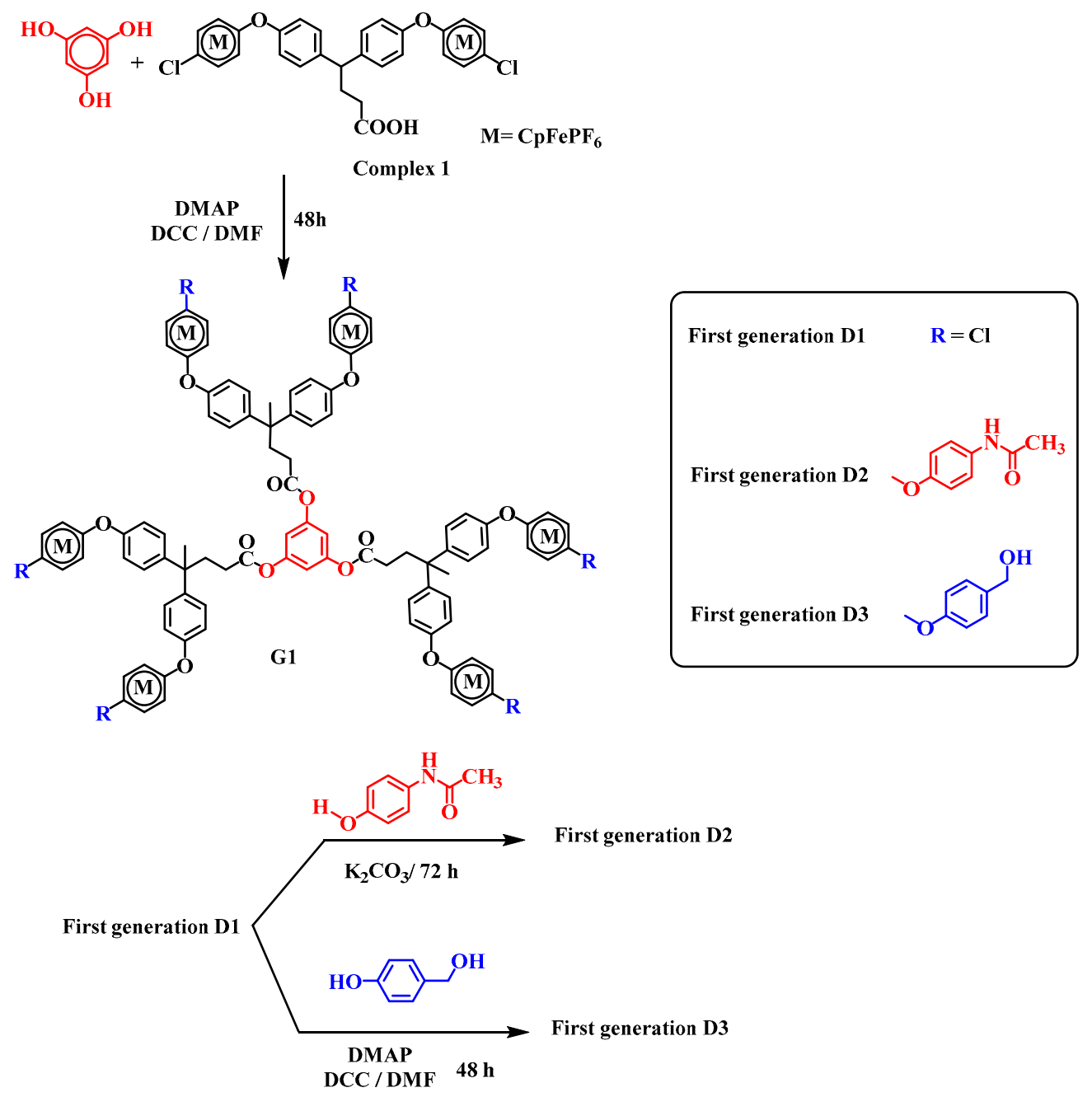

Scheme 1. Schematic representation of the synthesis of first-generation dendrimers (D1-D3). 


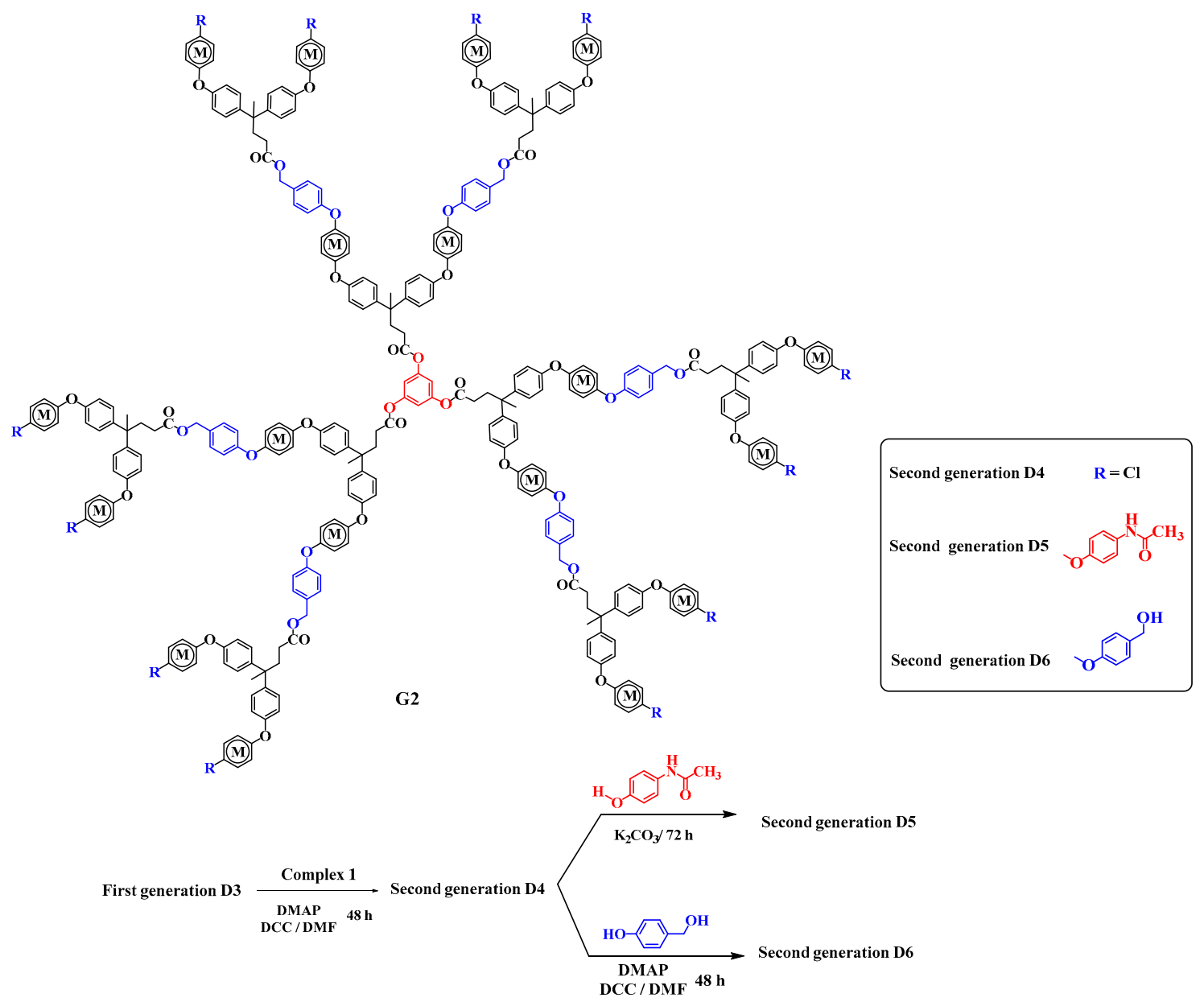

Scheme 2. Schematic representation of the synthesis of second-generation dendrimers (D4-D6). 


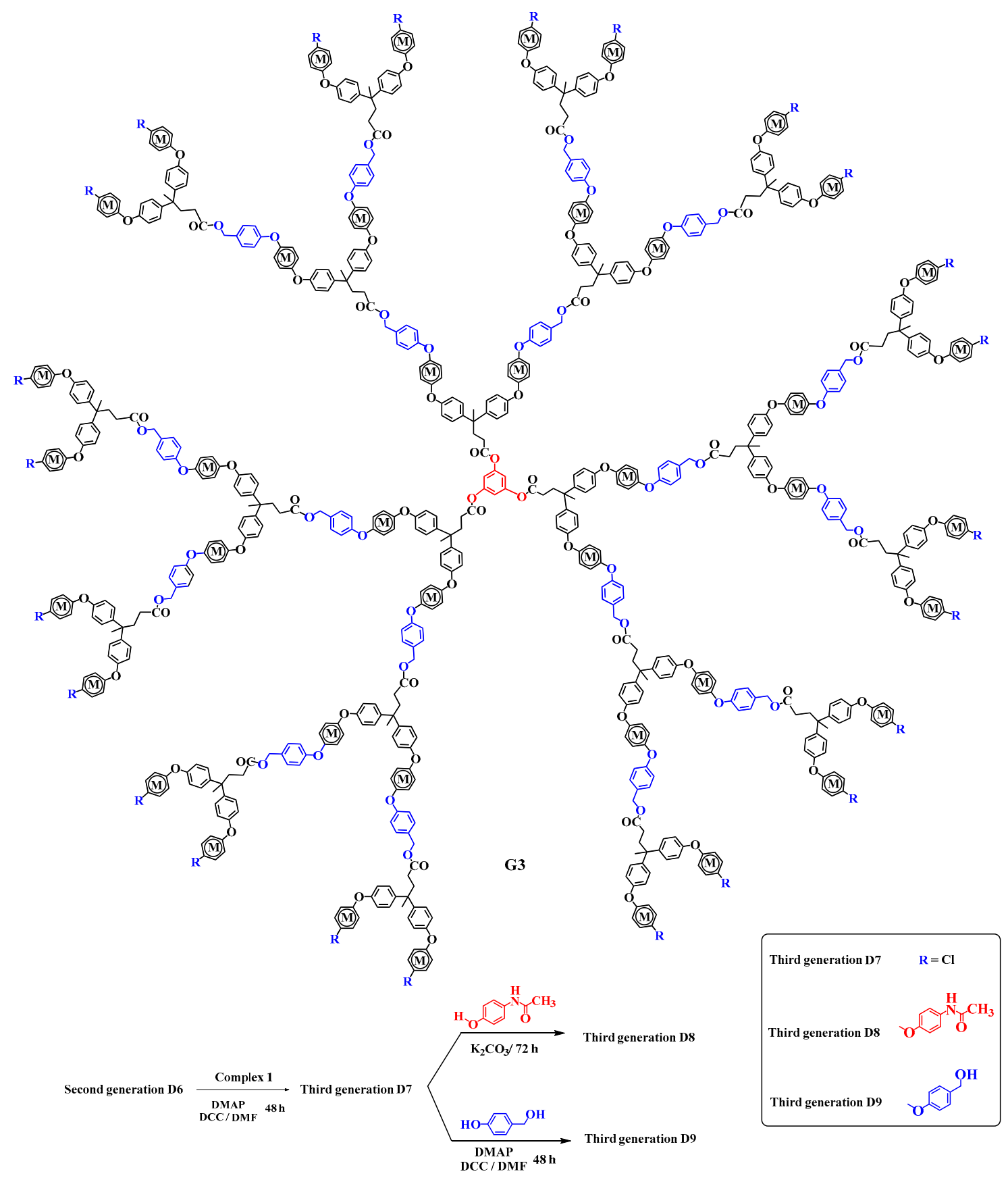

Scheme 3. Schematic representation of the synthesis of third-generation dendrimers (D7-D9). 


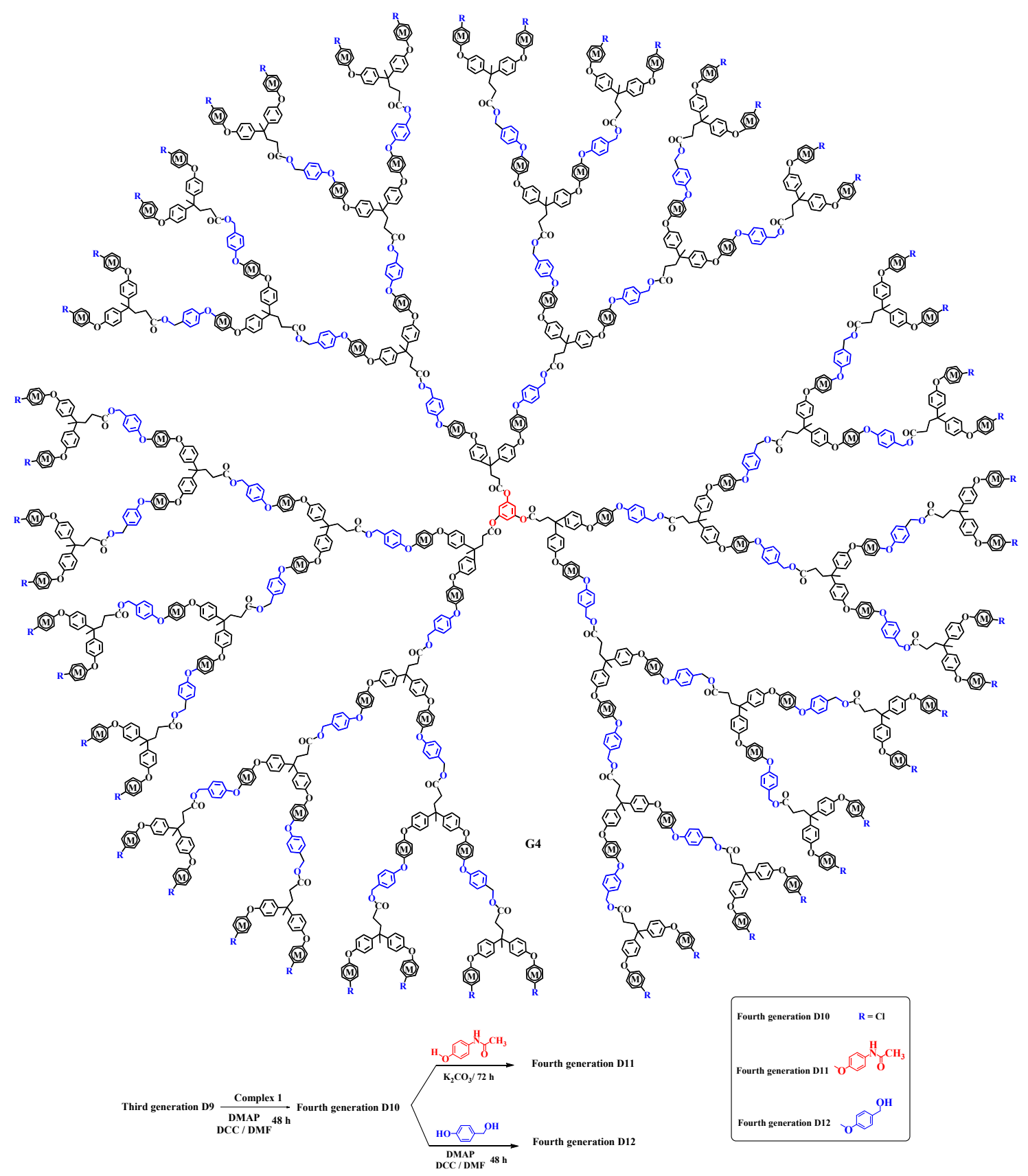

Scheme 4. Schematic representation of the synthesis of fourth-generation dendrimers (D10-D12).

${ }^{1} \mathrm{H}$ and ${ }^{13} \mathrm{C}$ NMR and infrared (IR) spectroscopy as well as elemental analysis were used to characterize and identify the new dendrimers. For instance, second-generation D4 showed a downfield peak at $6.82 \mathrm{ppm}$, which referred to 24 protons in the twelve complexed outer aryl groups attached to the chloro end groups, and another upfield peak at $6.43 \mathrm{ppm}$, which represented 24 protons in the 12 complexed outer aryl groups attached to the etheric oxygen groups plus the 24 protons of the six iron-complexes in the first layer of the dendrimer. Additionally, a peak appeared at $5.28 \mathrm{ppm}$, which corresponded to the protons in the $\mathrm{Cp}$ attached to the chloro- end groups and another peak at 5.22 ppm, which corresponding to the 6 inner cyclopentadiene complexes. The second-generation D5 showed one upfield peak appearing at $6.25 \mathrm{ppm}$; the upfield peak was indicative of the protons close to the peripheral attached to the etheric oxygen groups. The equivalent protons of the iron-complexed arene ligand, indicated a successful $S_{N} A r$ reaction since, as discussed in the literature $[20,34,51]$, a successful $S_{N} A r$ reaction with phenolic nucleophiles converts the non-equivalent aromatic protons of 
iron-complexed chlorophenoxyl into equivalent protons. The (NH) peak of secondary amine groups in paracetamol appeared at $10.13 \mathrm{ppm}$. The Cp peak shifted to the upfield region and appeared at $5.22 \mathrm{ppm}$, corresponded to the protons close to the etheric oxygen groups which replaced the chloro end groups. Also, in ${ }^{1} \mathrm{H}$ NMR spectroscopy the appearance of two Cp peaks again at 5.28 and 5.22 ppm for third-generation D7, was due to the non-equivalence of the surrounding groups at the para positions. The first peak at $5.22 \mathrm{ppm}$ corresponded to the inner protons close to the etheric oxygen groups while the second peak shifted downfield at $5.28 \mathrm{ppm}$, due to the presence of the chloro end group. It is also worth noting that both $\mathrm{Cp}$ peaks showed integration in agreement with the ratio of $\mathrm{Cp}$ protons pendent to the chloro-arenes in the periphery to those in the inner arenes with the etheric bridges. Also, of the three denoted peaks at 6.81, 6.40, and $6.26 \mathrm{ppm}$, the upfield peak at 6.26 ppm referred to the 72 protons in the eighteen inner complexed aryl groups attached to the etheric oxygen groups, while the other peaks observed at 6.82 and 6.43 ppm corresponded to the 96 protons in the 24 complexed outer aryl rings with the chloro end groups. In addition, the $\mathrm{OH}$ peak at 5.33 ppm in second-generation D6 disappeared in the third-generation D7. In the case of the third-generation dendrimer third-generation D8, only one peak at 6.25 ppm referred to 168 protons for all aryl complexed groups in inert and outer spheres. As well, the NH groups of paracetamols appeared again at $10.13 \mathrm{ppm}$, and one $\mathrm{Cp}$ shifted upfield at $5.22 \mathrm{ppm}$ referring to the 210 equivalent protons in both inner and outer rings which are surrounded by etheric oxygen groups at the para positions.

Successful synthesis of these dendrimers was also confirmed by using ${ }^{13} \mathrm{C}$ NMR spectroscopy. For example, carbonyl groups showed one peak around $170.00 \mathrm{ppm}$ for the first generation D1 and increased by increasing the number of generations. Similarly, one peak in the dendrimers D2, D3, D5, D6, D8, D9, D11, and D12 corresponded to the Cp carbons around $79.00 \mathrm{ppm}$. While two distinct $\mathrm{Cp}$ carbon peaks resonated around 80.00 and 79.00 ppm, for dendrimers D1, D4, D7, and D10 there was a very clear difference between $\mathrm{Cp}$ peaks coordinated to the aryl groups with chloro and hydroxyl groups. Furthermore, in the presence of the peripheral chloro groups, the complexed carbons vibrated around 87.50 and $76.50 \mathrm{ppm}$, while the uncomplexed carbons with ester linkages located at 77.50 and $75.50 \mathrm{ppm}$. For example, in the first-generation D3 with equivalent ester linkages resonated at $174.00 \mathrm{ppm}$, the complexed carbons resonated at 74.85 and $74.48 \mathrm{ppm}$, and the Cp carbons appeared at 78.83 ppm. However, in dendrimer second-generation D4 with non-equivalent linkages, the complexed carbons pointed up at 86.43 and 74.71 ppm, while Cps which had two non-equivalent environments led to the appearance of two peaks at 78.95 and $77.44 \mathrm{ppm}$. Uncomplexed carbons were located in the specific area around $130.00 \mathrm{ppm}$ and quaternary carbons were detected around 172.80 ppm.

The ATR-FTIR absorption spectra showed the presence and characteristic bands of hydroxyl, amine, ester, and ether groups, respectively, around 3400, 3330, and $1220 \mathrm{~cm}^{-1}$. The elemental analysis further confirmed the dendrimers' formation as outlined in the experimental section. The solubility of the dendrimers in organic solvents decreased with increasing molecular weight. However, all of them were soluble in polar aprotic solvents such as DMF and DMSO.

The morphology images of the dendrimers attached to paracetamol first-generation D2, second-generation D5, third-generation D8, and fourth-generation D11 were taken by scanning electron microscopy (SEM), to show the difference between each generation. The microscopic images demonstrated the amorphous character of the dendrimers as shown in Figure 1. 

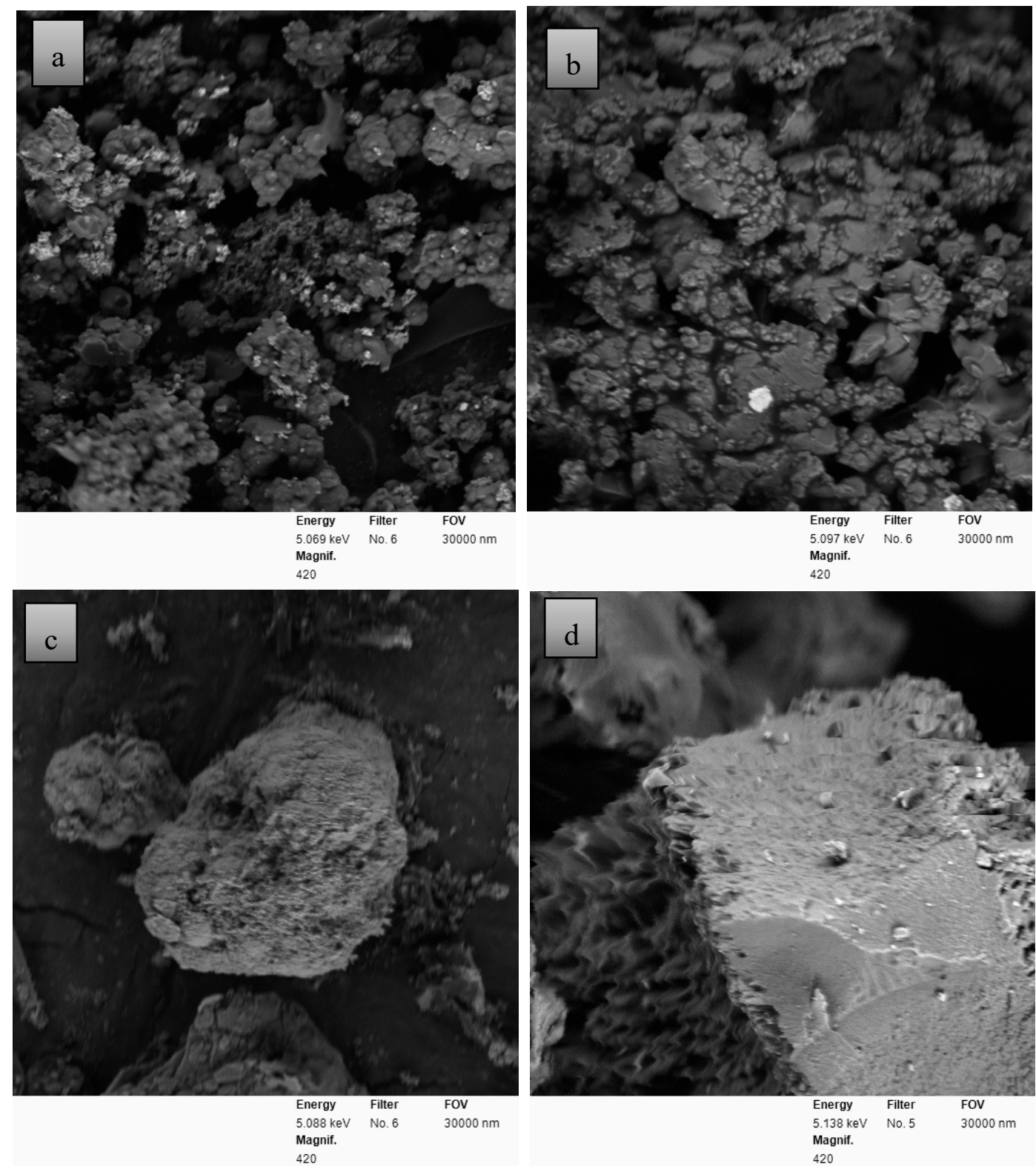

Figure 1. Scanning electron microscope (SEM) images (a) first-generation D2, (b) second-generation D5, (c) third-generation D8, (d) fourth-generation D11.

As can be seen in Figure 1a, the first-generation D2 showed particles of almost the same size and shape arranged in a flower-like morphology with relatively uniform particle distribution. The image for the second-generation D5 indicates an irregular shape with a slight aggregation of different sizes and shapes, with both large and small particles appearing with spaces between them. Although both first and second-generation had almost the same morphology, the second-generation D5 composite was slightly larger than first-generation D2, as presented in Figure 1b. A sponge-like shape was shown in the third-generation D8 and appeared as an irregular globule with many holes inside it as seen in Figure 1c. A rough surface was observed with large size in the fourth-generation D11, which contains ninety iron moieties, resulting in the particles having a rock-like appearance with sharp edges Figure $1 \mathrm{~d}$. 


\subsection{Electrochemical Properties}

The redox properties of the dendrimers were studied using the cyclic voltammetry technique. $\eta^{6}$-aryl- $\eta^{5}$-cyclopentadienyliron(II) is redox-active in both the molecular and macromolecular scale and, therefore, the electrochemistry of these dendrimers features several remarkable trends [52-54]. The synthetic procedure allowed the including of redox-active iron centers $\eta^{6}$-aryl- $\eta^{5}$-cyclopentadienyliron (II) in the dendritic arms at every repeated synthetic step to form spheres of redox centers and the number of the redox centers increased from 6 units in the first-generation to 90 units in the fourth generation. The experiments were performed at temperatures of $0{ }^{\circ} \mathrm{C}$ in a solution of $0.1 \mathrm{M} \mathrm{Bu}_{4} \mathrm{NPF}_{6}$ using propylene carbonate as a supporting electrolyte, an $\mathrm{Ag} / \mathrm{Ag}^{+}$reference electrode, a glassy carbon working electrode, and a Pt wire counter electrode. The potential was scanned in the range of 0 to $-2.0 \mathrm{~V}$. All dendrimers exhibited a single redox wave with cathodic peak $\left(\mathrm{E}_{\mathrm{pc}}\right)$ and anodic peak $\left(\mathrm{E}_{\mathrm{pa}}\right)$ values, with changes in their intensities dependent on dendrimer generation.

At room temperature dendrimers exhibited an irreversible redox process, while at $0{ }^{\circ} \mathrm{C}$ all dendrimers underwent reversible redox process, (Figure 2). The average $E_{1 / 2}$ values were between -1.22 and $-1.25 \mathrm{~V}$, for first-generation dendrimers and the single redox was reasonable due to the equivalence of these redox centers. Dendrimers in the second-generation had a more negative shift and there was an increase in intensities in both reduction and oxidation peaks with the broadening of the peaks, as previously reported [55]. This shift was due to the higher number of cationic irons in this generation and the average $E_{1 / 2}$ values were around $-1.26 \mathrm{~V}$.

The average $E_{1 / 2}$ values were recorded to be up to $-1.35 \mathrm{~V}$ in the fourth generation, a more negative shift appeared due to the increase of the number of redox-active centers, thus, the increase in their redox wave intensities. Also, the difference in the $E_{1 / 2}$ values from first to the fourth generation was around $-0.13 \mathrm{~V}$ as can be seen in Table 1 due to the greater number of cationic centers.

A split of the reverse peak was expected due to the different layers of the cationic redox dendrimers with different generations, but the high rate of electron transfer between the electrodes and iron centers restricted the splitting of the redox waves. Also, overlapped cathodic currents appeared from the reduction of iron centers consonant with previous studies [33].

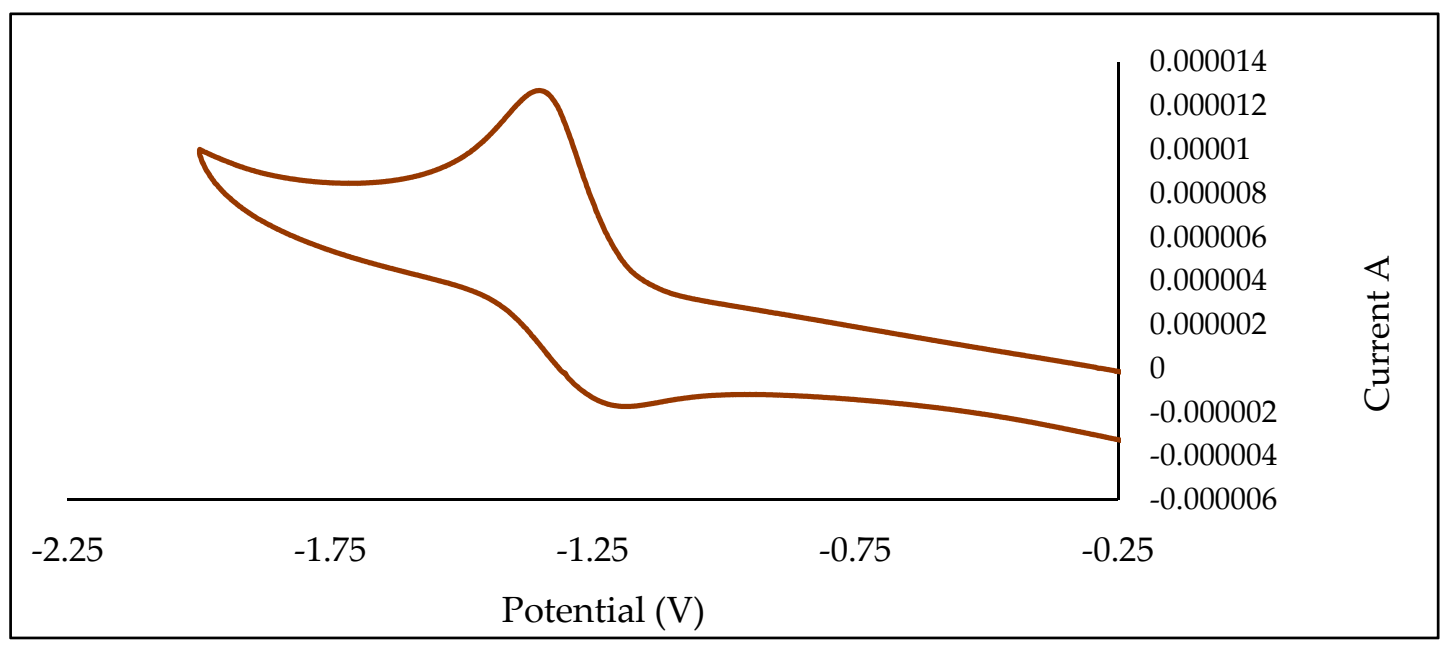

Figure 2. Representative cyclic voltammogram of second-generation D6, in $0.1 \mathrm{M} \mathrm{Bu}_{4} \mathrm{NPF}_{6}$ in propylene carbonate, scan rate $=0.2 \mathrm{~V} / \mathrm{s}$, at $-15^{\circ} \mathrm{C}$. 
Table 1. Redox activity of dendrimers $\mathbf{1 - 1 2}$ at $0{ }^{\circ} \mathrm{C}$.

\begin{tabular}{cccc}
\hline Dendrimers & $\mathrm{E}_{\mathbf{p c}}(\mathrm{V})$ & $\mathrm{E}_{\mathbf{p a}}(\mathrm{V})$ & $\mathrm{E}_{\mathbf{1} / \mathbf{2}}(\mathrm{V})$ \\
\hline D1 & -1.26 & -1.21 & -1.24 \\
\hline D2 & -1.26 & -1.24 & -1.25 \\
\hline D3 & -1.28 & -1.16 & -1.22 \\
\hline D4 & -1.32 & -1.21 & -1.27 \\
\hline D5 & -1.28 & -1.26 & -1.27 \\
\hline D6 & -1.29 & -1.23 & -1.26 \\
\hline D7 & -1.32 & -1.14 & -1.23 \\
\hline D8 & -1.32 & -1.36 & -1.34 \\
\hline D9 & -1.33 & -1.14 & -1.24 \\
\hline D10 & -1.37 & -1.16 & -1.27 \\
\hline D11 & -1.34 & -1.36 & -1.35 \\
\hline D12 & -1.33 & -1.18 & -1.26 \\
\hline
\end{tabular}

\subsection{Thermal Analysis}

The thermal stability of the dendrimers was investigated using TGA. The experiments were performed at atmospheric pressure under a nitrogen atmosphere. The samples' weight loss as functions of temperature were recorded continuously, in the range of $0-1000{ }^{\circ} \mathrm{C}$. The thermal decomposition of all dendrimers was begun around $190^{\circ} \mathrm{C}$, followed by a major weight loss in the temperature range of 350 to $600{ }^{\circ} \mathrm{C}$. Some dendrimers displayed a third degradation step with minor weight losses above $850^{\circ} \mathrm{C}$, as shown in Figure 3 and Table 2.

The first decomposition is due to the losses of cationic cyclopentadienyl iron in the dendrimers' arms, which exhibited around $15-25 \%$ loss at the temperature between $190-250{ }^{\circ} \mathrm{C}$ for as the first degradation of all dendrimers [31,56,57].

Each generation has almost the same degradation steps, for example, in the first-generation D2, the first loss was at $200-220{ }^{\circ} \mathrm{C}$ with $15 \%$. The thermogram also showed a second massive weight loss accounting for $75 \%$ of its weight beginning at $380^{\circ} \mathrm{C}$ and continues to decompose until beyond $580{ }^{\circ} \mathrm{C}$, with $10 \%$ remaining at the end which referred to the iron residue. A broad range was noticed for the second-generation D5 in its first degradation, with about $25 \%$ loss at a temperature between $190-250^{\circ} \mathrm{C}$. In addition, two more degradation steps occurred, one at the range of $400{ }^{\circ} \mathrm{C}$ to $500{ }^{\circ} \mathrm{C}$ with $35 \%$ loss and the other one at $800{ }^{\circ} \mathrm{C}$ to $990{ }^{\circ} \mathrm{C}$ with only $10 \%$ loss, leaving $30 \%$ as iron residue. The third-generation D8 with 42 iron centers had $20 \%$ loss between $200-210{ }^{\circ} \mathrm{C}$, and also showed one main degradation step, with $70 \%$ loss beginning at $300{ }^{\circ} \mathrm{C}$ and ending at $500^{\circ} \mathrm{C}$. The residual contents in this generation were found to be around $10 \%$. Lastly, a loss of $20 \%$ was measured between 210-230 ${ }^{\circ} \mathrm{C}$ for the first degradation of the fourth-generation D11 with 90 iron centers. Another smooth decomposition of the remaining complex was observed directly after the first degradation and ended after $1000{ }^{\circ} \mathrm{C}$, with more than $70 \%$ loss. 


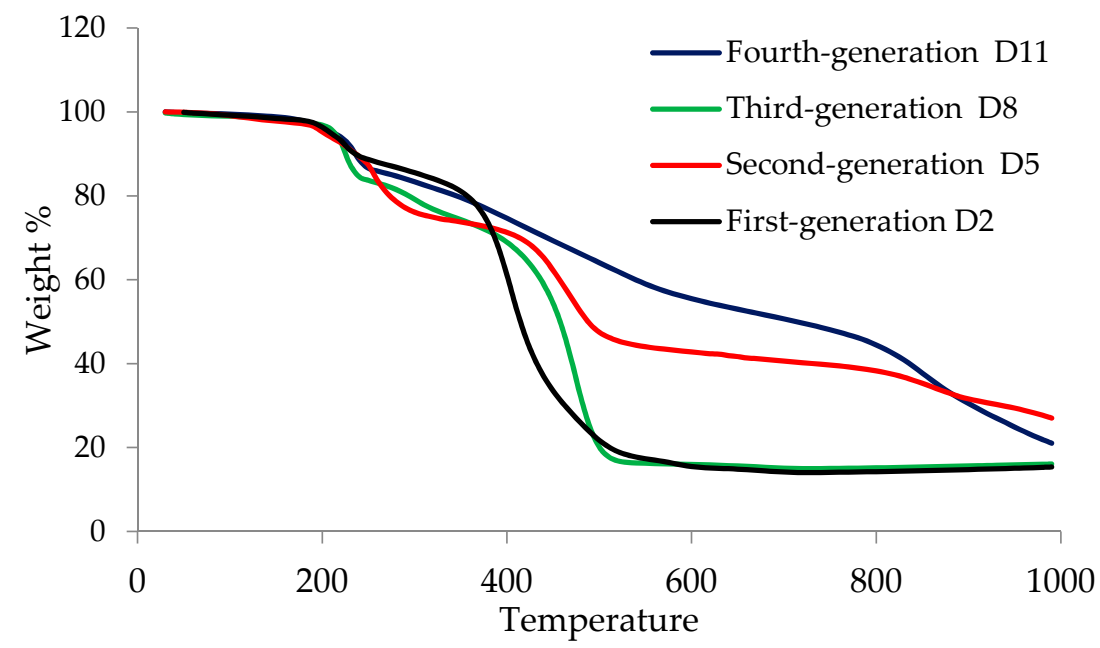

Figure 3. Thermogravimetric analysis (TGA) of generation first-generation D2, second-generation D5, third-generation D8, and fourth-generation D11.

Table 2. Thermal analysis of dendrimers 1-12.

\begin{tabular}{|c|c|c|c|}
\hline Dendrimer & Weight Loss (\%) & $\mathrm{T}_{\text {onset }}{ }^{\circ} \mathrm{C}$ & $\mathrm{T}_{\text {endset }}{ }^{\circ} \mathrm{C}$ \\
\hline \multirow{3}{*}{ first-generation D1 } & 20 & 190 & 220 \\
\hline & 60 & 345 & 350 \\
\hline & 10 & 500 & 550 \\
\hline \multirow{3}{*}{ first-generation D2 } & 15 & 200 & 220 \\
\hline & 75 & 380 & 580 \\
\hline & 10 & 600 & 1000 \\
\hline \multirow{3}{*}{ first-generation D3 } & 15 & 200 & 220 \\
\hline & 70 & 390 & 550 \\
\hline & 15 & 560 & 620 \\
\hline \multirow{3}{*}{ second-generation D4 } & 30 & 195 & 225 \\
\hline & 35 & 355 & 530 \\
\hline & 25 & 680 & 750 \\
\hline \multirow{3}{*}{ second-generation D5 } & 25 & 190 & 250 \\
\hline & 35 & 400 & 500 \\
\hline & 10 & 800 & 990 \\
\hline \multirow{3}{*}{ second-generation D6 } & 20 & 190 & 230 \\
\hline & 20 & 420 & 500 \\
\hline & 30 & 850 & 900 \\
\hline \multirow{3}{*}{ third-generation D7 } & 30 & 205 & 230 \\
\hline & 25 & 406 & 510 \\
\hline & 25 & 800 & 980 \\
\hline \multirow{3}{*}{ third-generation D8 } & 20 & 200 & 210 \\
\hline & 70 & 300 & 500 \\
\hline & 10 & 600 & 1000 \\
\hline \multirow{3}{*}{ third-generation D9 } & 25 & 200 & 220 \\
\hline & 45 & 420 & 500 \\
\hline & 15 & 880 & 990 \\
\hline \multirow{3}{*}{ fourth-generation D10 } & 15 & 200 & 235 \\
\hline & 50 & 340 & 495 \\
\hline & 15 & 630 & 790 \\
\hline \multirow{3}{*}{ fourth-generation D11 } & 20 & 210 & 230 \\
\hline & 70 & 250 & 1000 \\
\hline & 10 & 1000 & 1000 \\
\hline \multirow{3}{*}{ fourth-generation D12 } & 30 & 220 & 240 \\
\hline & 25 & 380 & 480 \\
\hline & 10 & 700 & 900 \\
\hline
\end{tabular}




\subsection{Microbial Activity of Synthesized Dendrimers}

The dendrimers were assayed against a broad spectrum of pathogenic microbes that included Gram-positive bacteria: methicillin-resistant Staphylococcus aureus (MRSA), vancomycin-resistant Enterococcus faecium (VRE), and Staphylococcus warneri; Gram-negative bacteria: Pseudomonas aeruginosa and Proteus vulgaris; and fungus Candida albicans. The concentrations at which inhibition of $50 \%$ of the growth was observed $\left(\mathrm{IC}_{50}\right)$ and the minimum inhibitory concentration for inhibition of $90 \%$ of growth $\left(\mathrm{MIC}_{90}\right)$, were determined. At the tested concentrations, all dendrimers were inactive against the Gram-negative bacteria and C. albicans. Most of the dendrimers were active against the Gram-positive bacteria with the minimum inhibitory concentration $\left(\mathrm{MIC}_{90}\right)$ in the low micromolar range (Table 3).

The $\mathrm{IC}_{50}$ values showed in our study are equal or even lower than the antimicrobials in clinical use against MRSA and VRE. Dendrimers having chloro end groups exhibited notable antibacterial activity but not as much as the other end groups. We found dendrimers containing paracetamol groups in the outer spheres were more efficient against Gram-positive bacteria and slightly more efficacious compared to dendrimers carrying hydroxyl molecules in the periphery. It is likely that the presence of a terminal paracetamol group was responsible for the observed increase in efficacy in antimicrobial activity of their dendrimers (possibly due to target interactions with the $\mathrm{N}-\mathrm{H}$ terminal group) $[32,34,58]$. This trend could show the action of primary amines against Gram-positive bacteria, which may also be related to the bacterial membrane permeability.

Recently, many studies have reported that the presence of the hydroxyl group at various positions of some compounds like flavonoids and coumarins enhanced their antibacterial activity [59-62]. In addition, the flexible short aliphatic chains attached to the hydroxyl group facilitates the interaction with the bacterial cytoplasmic membrane. The improvement of the antibacterial activity of different dendrimers with $\mathrm{OH}$ and $\mathrm{NH}_{2}$ end groups is due to the hindrance of bacterial biofilm production, bacterial cell membrane damage, and hindrance of virulence factors like enzymes and toxins [59]. The polarity of the $\mathrm{NH}_{2}, \mathrm{OH}$ group and the opportunity of intramolecular hydrogen bond formation could further role in these dendrimers and influence their antibacterial efficacy, comparable to the mechanism of action as rifampicin, which is a powerful antibiotic against mycobacterial infections as well as a broad range of Gram-positive and Gram-negative bacteria [63]. The geometry of these dendrimers and the chance of formation of the stable zwitterions by intermolecular hydrogen bonds provide high antimicrobial activity [63]. By dissolving rifampicin in water, the antibacterial ability was increased by both intra and intermolecular hydrogen bonding with water molecules which gave an additional stabilization on its zwitterionic form [63]. Our dendrimers with $\mathrm{OH}$ and $\mathrm{NH}_{2}$ end groups can form intra and intermolecular hydrogen bonding with DMSO molecules which gave them the minimum inhibitor activities than the other dendrimers by supporting the zwitterion form.

The activity of our dendrimers is also due to the production of reactive oxygen species (ROS) through electron transfer to oxygen molecules due to the presence of the redox-active $\mathrm{Cp}-\mathrm{Fe}^{\mathrm{II}}$-arene complex, as before confirmed $[64,65]$. The presence of ROS influences oxidative strain, a cellular protection technique employed against a broad spectrum of microbes [65-67].

Consequently, the presence of $\eta^{6}$-arene- $\eta^{5}$-cyclopentadienyliron(II) complex provided a further explanation for the excellent antibacterial activity against a wide spectrum of pathogenic microbes, particularly in the highest generation, due to the increase of the number of the $\eta^{6}$-arene- $\eta^{5}$-cyclopentadienyliron(II) complexes $[33,43]$. It is useful to mention that a single molecule of $\mathrm{Cp}-\mathrm{Fe}^{\mathrm{II}}$-arene complex reported an $\mathrm{IC}_{50}$ of $28.9 \mu \mathrm{M}$ for MRSA, no activity has been shown for VRE, and $38.8 \mu \mathrm{M}$ for Staphylococcus warneri [43], which demonstrated that the $\mathrm{Cp}-\mathrm{Fe}^{\mathrm{II}}$-arene complexes were themselves active against some types of Gram-positive bacteria, as previously reported [43]. Increasing the number of the redox-active $\mathrm{Cp}-\mathrm{Fe}^{\mathrm{II}}$-arene complexes increases the action of $\mathrm{Cp}-\mathrm{Fe}^{\mathrm{II}}$-arene on the pathogenic microbes by enhancing the interaction with the cell membrane and induction of oxidative stress on bacteria $[33,34,43]$.

For example, for the second-generation D4 (ending with chloro groups), an $\mathrm{IC}_{50}$ of $2.99 \mu \mathrm{M}$ was observed for MRSA, $3.03 \mu \mathrm{M}$ for VRE and $2.21 \mu \mathrm{M}$ for Staphylococcus warneri. For the second-generation 
D6 (ending with terminal hydroxyl groups) an $\mathrm{IC}_{50}$ of $2.70 \mu \mathrm{M}$ was reported for MRSA, $2.64 \mu \mathrm{M}$ for VRE, and $1.74 \mu \mathrm{M}$ for Staphylococcus warneri. In the case of the second-generation D5 (which ended in terminal paracetamol groups) an $\mathrm{IC}_{50}$ of $1.11 \mu \mathrm{M}$ was observed for MRSA, $2.15 \mu \mathrm{M}$ was recorded for VRE, and $1.14 \mu \mathrm{M}$ for Staphylococcus warneri. Additionally, an increase in antibacterial activity was also recorded from first-generation dendrimers compared to higher generations. For example, for dendrimers having terminal paracetamol in the periphery, the first-generation D2 exhibited an $\mathrm{IC}_{50}$ of $2.32 \mu \mathrm{M}$ for MRSA, $4.19 \mu \mathrm{M}$ for VRE, and $2.51 \mu \mathrm{M}$ for Staphylococcus warneri. The second-generation D5 displayed $\mathrm{IC}_{50} 1.11 \mu \mathrm{M}$ for MRSA, $2.15 \mu \mathrm{M}$ for VRE, and $1.14 \mu \mathrm{M}$ for Staphylococcus warneri, while the third-generation D8 showed an $\mathrm{IC}_{50}$ of $0.65 \mu \mathrm{M}$ for MRSA, 1.69 $\mu \mathrm{M}$ for VRE, and $0.86 \mu \mathrm{M}$ for Staphylococcus warneri. Excellent results were achieved with the fourth-generation D11, which presented $\mathrm{IC}_{50}$ of $0.53 \mu \mathrm{M}$ for MRSA, $1.02 \mu \mathrm{M}$ for VRE, and $0.73 \mu \mathrm{M}$ for Staphylococcus warneri. A plausible explanation for this effect is due to the increase in the total surface area of the dendrimer periphery, increasing the number of available functionalized terminal groups that can interfere with the antibacterial target. Of the dendrimers tested, fourth-generation D11 showed the most potent antibacterial activity against Gram-positive bacteria with efficacies better than the antimicrobial controls, vancomycin, and rifampicin (Table 3).

Table 3. Microbial activity of dendrimers D1-D12.

\begin{tabular}{|c|c|c|c|c|c|c|}
\hline \multirow[t]{2}{*}{ Dendrimer } & \multicolumn{2}{|c|}{ MRSA } & \multicolumn{2}{|c|}{ VRE } & \multicolumn{2}{|c|}{ Staphylococcus warneri } \\
\hline & $\mathrm{IC}_{50}(\mu \mathrm{M})$ & $\operatorname{MIC}(\mu \mathrm{M})$ & $\mathrm{IC}_{50}(\mu \mathrm{M})$ & $\operatorname{MIC}(\mu \mathrm{M})$ & $\mathrm{IC}_{50}(\mu \mathrm{M})$ & $\operatorname{MIC}(\mu \mathrm{M})$ \\
\hline $\mathrm{Cp}-\mathrm{Fe}^{\mathrm{II}}$-arene $\mathrm{e}^{71}$ & 28.9 & 77.5 & - & - & 38.8 & 77.5 \\
\hline first-generation D1 & $3.47 \pm 0.00$ & 16 & $5.07 \pm 0.65$ & 32 & $3.54 \pm 0.07$ & 16 \\
\hline first-generation D2 & $2.32 \pm 0.31$ & 16 & $4.19 \pm 0.53$ & $64-32$ & $2.51 \pm 0.80$ & $16-8$ \\
\hline first-generation D3 & $3.04 \pm 0.00$ & 16 & $6.08 \pm 0.37$ & 32 & $2.99 \pm 0.80$ & 16 \\
\hline second-generation D4 & $2.99 \pm 0.04$ & 8 & $3.03 \pm 0.09$ & 16 & $2.21 \pm 0.23$ & $16-8$ \\
\hline second-generation D5 & $1.11 \pm 0.09$ & $32-16$ & $2.15 \pm 0.21$ & 64 & $1.14 \pm 0.11$ & $32-16$ \\
\hline second-generation D6 & $2.70 \pm 0.41$ & 8 & $2.64 \pm 0.00$ & 32 & $1.74 \pm 0.23$ & $16-8$ \\
\hline third-generation D7 & $0.97 \pm 0.04$ & 16 & $2.95 \pm 0.00$ & 32 & $2.07 \pm 0.31$ & 32 \\
\hline third-generation D8 & $0.65 \pm 0.19$ & 32 & $1.69 \pm 0.22$ & 64 & $0.86 \pm 0.02$ & 32 \\
\hline third-generation D9 & $0.79 \pm 0.40$ & $64-32$ & $2.48 \pm 0.06$ & 64 & $1.24 \pm 0.07$ & 32 \\
\hline fourth-generation D10 & $0.82 \pm 0.02$ & 16 & $1.93 \pm 0.01$ & 32 & $1.22 \pm 0.02$ & 16 \\
\hline fourth-generation D11 & $0.53 \pm 0.30$ & $64-32$ & $1.02 \pm 0.02$ & 64 & $0.73 \pm 0.21$ & 64 \\
\hline $\begin{array}{l}\text { fourth-generation D12 } \\
\text { paracetamol }\end{array}$ & $\begin{array}{c}0.57 \pm 0.03 \\
>128\end{array}$ & 16 & $\begin{array}{c}1.62 \pm 0.02 \\
>128\end{array}$ & 64 & $\begin{array}{c}0.97 \pm 0.03 \\
>128\end{array}$ & 16 \\
\hline $\begin{array}{l}\text { vancomycin } \\
\text { rifampicin }\end{array}$ & $0.6 \pm 0.10$ & 1.4 & $3.5 \pm 0.85$ & 4.9 & $0.5 \pm 0.10$ & 0.7 \\
\hline
\end{tabular}

The dendrimers were tested at eight different concentrations obtained by serial dilution of the initial concentration, $128 \mu \mathrm{g} / \mathrm{mL}$, to a final concentration $1 \mu \mathrm{g} / \mathrm{mL}$, in $2 \%$ DMSO.

Compared with commercial paracetamol, the biological activity tests showed that the synthesized dendrimers D2, D5, D8, and D11 with paracetamol moieties have higher antibacterial activity against these three Gram-positive bacteria in addition to the central analgesic effect. The inhibition was enhanced by increasing the number of $\eta^{6}$-arene- $\eta^{5}$-cyclopentadienyliron(II) complex from $6,18,42$, and 90 in the dendritic branches.

\section{Experimental}

\subsection{Materials}

All chemicals and reagents were purchased from Sigma-Aldrich, Oakville, Ontario, Canada and were used without any further purification. All solvents were dried and stored over $3 \AA$ molecular sieves before being used. The synthesis of the organoiron complex 1 followed previously reported procedures $[68,69]$. 


\subsection{Instrumentation}

A Bruker Avance nuclear magnetic resonance (NMR) spectrometer $\left({ }^{1} \mathrm{H}, 300 \mathrm{MHz}\right.$ and $\left.{ }^{13} \mathrm{C}, 75 \mathrm{MHz}\right)$, Billerica, Middlesex County, Massachusetts, US, was used to characterize all synthesized complexes in DMSO- $\mathrm{d}_{6}$ with the chemical signals referenced to solvent residual signal in ppm. Attenuated total reflection Fourier transform IR (ATR-FTIR) absorption spectroscopic measurements were acquired on a Bruker Alpha FTIR spectrometer Alpha-P, Billerica, Middlesex County, Massachusetts, US. Cyclic voltammetric experiments were carried out on a Princeton Applied Research/EG\&G Model 263 potentiostat/galvanostat, champaign, USA. Using glassy carbon working electrode, Pt counter electrode, and Ag reference electrode. The experiments, which were carried out at a scan rate between 0.1 and $1.5 \mathrm{Vs}^{-1}$ at $0{ }^{\circ} \mathrm{C}$ under nitrogen atmosphere in degassed propylene carbonate as solvent and tetrabutylammonium hexafluorophosphate as supporting electrolyte. Scanning electron micrographs were obtained on an LVEM5 benchtop instrument which operates at $5 \mathrm{kV}$, Delong America, Montreal Quebec Canada. Powdered samples were cast onto stubs, dried under vacuum, and coated with gold/palladium before imaging. TGA was conducted in platinum pans under nitrogen at a heating rate of $10^{\circ} \mathrm{C}$ on a TA Instruments TGA Q500 Mississauga, Canada.

\subsection{Antimicrobial Assay}

All microbroth antibiotic susceptibility testing was carried out according to Overy et al. [70] using the following pathogens: methicillin-resistant Staphylococcus aureus ATCC 33591 (MRSA); Staphylococcus warneri ATCC 17917, vancomycin-resistant Enterococcus faecium EF379 (VRE); Pseudomonas aeruginosa ATCC 14210, Proteus vulgaris ATCC 12454, and Candida albicans ATCC 14035. Complexes were serially diluted to generate a range of eight concentrations $(128 \mu \mathrm{g} / \mathrm{mL}$ to $1 \mu \mathrm{g} / \mathrm{mL})$ in a final well volume concentration of $2 \%$ DMSO (aq). Each plate contained three uninoculated positive controls, three untreated negative controls, and an appropriate concentration range of a control antibiotic (vancomycin for MRSA and Staphylococcus warneri, rifampicin for VRE, gentamycin for P. aeruginosa, ciprofloxacin for P. vulgaris, and nystatin for C. albicans). The optical density of the plate was recorded using a Thermo Scientific Varioskan Flash plate reader at $600 \mathrm{~nm}$ at time zero and then again after incubation of the plates for $22 \mathrm{~h}$ at $37^{\circ} \mathrm{C}$. After subtracting the time zero $\mathrm{OD}_{600}$ from the final reading, the percentages of microorganism survival relative to vehicle control wells were calculated.

\section{Synthesis and Characterization}

Four generations of redox-active organoiron dendrimers with three different end groups: chloro, hydroxyl, and paracetamol-terminated dendrimers were synthesized by using esterification reaction and the nucleophilic aromatic substitution $\left(\mathrm{S}_{\mathrm{N}} \mathrm{Ar}\right)$ reaction. These dendrimers had a different number of the end groups starting from 6 for the first-generation up to 48 in the fourth generation. Also, the dendrimers' branches contained between 6 to 90 units of the redox-active complex $\eta^{6}$-aryl- $\eta^{5}$-cyclopentadienyliron (II), which drove the reaction to occur in a moderated condition as well as improving the antibacterial efficiency of the dendrimers. Functionalization of the dendrimers with paracetamol yielded hybrid antimicrobial dendrimers with enhanced activity, especially at higher generation.

\subsection{General Procedure}

The core, 1, 3, 5-trihydroxybenzene (Phloroglucinol), and complex 1 were used to build first-generation dendrimer D1 (first-generation D1), by using Steglich esterification [69] with a molar ratio of 1:3. The solutions were stirred at $0{ }^{\circ} \mathrm{C}$ under nitrogen atmosphere for $15 \mathrm{~min}$. Then the closed system was stirred at room temperature for two days. The reaction mixture was cooled to $-25^{\circ} \mathrm{C}$ in a freezer for three hours, filtered to remove dicyclohexylurea (DHU) and then poured into $10 \% \mathrm{HCl}$ solution. The precipitate was filtrated and then dissolved in acetone, cooled again to $-25^{\circ} \mathrm{C}$ in a freezer for another three hours, filtered to remove any extra remaining DHU, and removal of the solvent by evaporation or reprecipitation in $10 \% \mathrm{HCl}$ solution gave rise to the products. The same 
methodology was used to synthesize higher generations dendrimers D4, D7, and D10, by using 1:6, 1:12, and 1:24 molar ratios, respectively.

Nucleophilic aromatic substitution reactions were used in the synthesis of dendrimer D2, D5, D8, and D11 by using 1:6, 1:12, 1:24, and 1:48 molar ratios of the core to paracetamol. The closed reaction mixtures were stirred in $\mathrm{DMF}$ and $\mathrm{K}_{2} \mathrm{CO}_{3}$ at room temperature between two to three days after flushing with nitrogen for $30 \mathrm{~min}$. Subsequently, the reaction mixtures were poured into a $10 \% \mathrm{HCl}$ solution, and $\mathrm{NH}_{4} \mathrm{PF}_{6}$ was added to precipitate the products. The products were collected by suction filtration and dried under vacuum at room temperature. The same method was used in the synthesis of dendrimer D3, D6, D9, and D12, by using 4-hydroxybenzyl alcohol instead of paracetamol with 1:6, 1:12, 1:24, and 1:48 molar ratios, respectively. The detailed synthetic methodologies for the dendrimers and their precursors, and spectroscopic characterization including ${ }^{1} \mathrm{H}$ and ${ }^{13} \mathrm{C}$ NMR, ATR-FTIR, and elemental analyses are reported below.

\subsection{Synthesis and Characterization of Dendrimers D1-D12}

\subsubsection{Chloro-Terminal Dendrimer (First-Generation D1)}

A $25 \mathrm{~mL}$ round-bottom flask was charged with bimetallic organoiron complex $\mathbf{1}(0.50 \mathrm{~g}, 0.48 \mathrm{mmol})$, tri-hydroxybenzene (0.02 g, $0.18 \mathrm{mmol})$, and 4-(Dimethylamino)pyridine (DMAP) $(0.11 \mathrm{~g}, 1.80 \mathrm{mmol}$ ), and dissolved in $10 \mathrm{~mL}$ of DMF. The solution was stirred in an ice bath under a nitrogen atmosphere while $\mathrm{N}, \mathrm{N}^{\prime}$-Dicyclohexylcarbodiimide (DCC) $(0.09 \mathrm{~g}, 0.48 \mathrm{mmol})$ was added over a 15 -min period. The reaction mixture was stirred under nitrogen for $24 \mathrm{~h}$. The product was poured into $100 \mathrm{~mL}$ of $10 \%$ $\mathrm{HCl}$ solution, and $\mathrm{NH}_{4} \mathrm{PF}_{6}(0.15 \mathrm{~g}, 1.9 \mathrm{mmol})$ was added to generate a precipitate.

Molecular weight $3190 \mathrm{~g} / \mathrm{mol}$ and yield 78\%. ATR-FTIR; $v_{\max } / \mathrm{cm}^{-1}: 2997(\mathrm{Ar}-\mathrm{C}), 2876(\mathrm{Cp}-\mathrm{C})$, $1698(\mathrm{CO}), 1223(\mathrm{C}-\mathrm{O}-\mathrm{C}) .{ }^{1} \mathrm{H}$ NMR data $\delta_{\mathrm{H}}\left(300 \mathrm{MHz}\right.$; DMSO- $\left.d_{6}\right): 7.41(12 \mathrm{H}, \mathrm{t}, J=8.4 \mathrm{~Hz}$, uncomplexed $\mathrm{Ar}-\mathrm{H}), 7.35(12 \mathrm{H}, \mathrm{d}, J=6.9 \mathrm{~Hz}$, uncomplexed $\mathrm{Ar}-\mathrm{H}), 7.11(3 \mathrm{H}$, s, uncomplexed $\mathrm{Ar}-\mathrm{H}), 6.82(12 \mathrm{H}, \mathrm{d}$, $J=6.0 \mathrm{~Hz}$, complexed Ar-H), $6.43(12 \mathrm{H}, \mathrm{d}, J=6.0 \mathrm{~Hz}$, complexed Ar-H), $5.29(30 \mathrm{H}, \mathrm{s}, \mathrm{Cp}-\mathrm{H}), 2.41$ $\left(6 \mathrm{H}, \mathrm{s}, \mathrm{CH}_{2}\right), 2.09\left(6 \mathrm{H}, \mathrm{s}, \mathrm{CH}_{2}\right), 1.73\left(9 \mathrm{H}, \mathrm{s}, \mathrm{CH}_{3}\right) .{ }^{13} \mathrm{C}$ NMR $\delta_{\mathrm{c}}\left(75 \mathrm{MHz}\right.$; DMSO- $\left.d_{6}\right): 152.17(\mathrm{CO})$, $146.77,132.85$, and 104.57 (quat-C), 132.86, 130.19, 121.14, 107.64, and 100.94 (uncomplexed Ar-C), 80.27 $(\mathrm{Cp}-\mathrm{C}), 87.71$ and 77.30 (complexed $\mathrm{Ar}-\mathrm{C}), 31.01$ and $25.85\left(\mathrm{CH}_{2}-\mathrm{C}\right), 28.31\left(\mathrm{CH}_{3}-\mathrm{C}\right)$. The elemental analysis of $\mathrm{C}_{123} \mathrm{H}_{102} \mathrm{O}_{12} \mathrm{Cl}_{6} \mathrm{Fe}_{6} \mathrm{P}_{6} \mathrm{~F}_{36}$ : calculated: \%C 46.32, \%H 3.22, and found \%C 46.84 and \% 2.99 .

\subsubsection{Paracetamol-Terminal Dendrimer (First-Generation D2)}

Dendrimer D2 was synthesized through a nucleophilic aromatic substitution reaction using dendrimer $\mathbf{D} \mathbf{1}$ and acetaminophen $\mathbf{2}$. A $25 \mathrm{~mL}$ round-bottom flask was charged with acetaminophen $(0.03 \mathrm{~g}, 0.18 \mathrm{mmol})$, dendrimer D1 (0.10 g, $0.03 \mathrm{mmol})$, and $\mathrm{K}_{2} \mathrm{CO}_{3}(0.13 \mathrm{~g}, 0.94 \mathrm{mmol})$, in $7 \mathrm{~mL}$ of DMF. The closed reaction mixture was stirred at room temperature for two days after flushing with nitrogen for $1 \mathrm{~h}$. Subsequently, the reaction mixture was poured into $100 \mathrm{~mL}$ of $\mathrm{HCl}$ solution, and $\mathrm{NH}_{4} \mathrm{PF}_{6}$ $(0.02 \mathrm{~g}, 0.24 \mathrm{mmol})$ was added to precipitate the product. The product was filtered and dried under vacuum resulting in a yellowish solid product.

Molecular weight $3878 \mathrm{~g} / \mathrm{mol}$ and yield 82\%. ATR-FTIR; $v_{\max } / \mathrm{cm}^{-1}: 3396$ (NH), 2956 (Ar-C), $2913(\mathrm{Cp}-\mathrm{C}), 1714$ (CO), 1243 (C-O-C). ${ }^{1} \mathrm{H}$ NMR data $\delta_{\mathrm{H}}\left(300 \mathrm{MHz}\right.$; DMSO- $\left.d_{6}\right): 10.11(6 \mathrm{H}, \mathrm{s}, \mathrm{NH})$, $7.34(12 \mathrm{H}, \mathrm{d}, J=8.4 \mathrm{~Hz}$, uncomplexed $\mathrm{Ar}-\mathrm{H}), 7.56(24 \mathrm{H}, \mathrm{d}, J=9.0 \mathrm{~Hz}$, uncomplexed Ar-H), 7.23 $(12 \mathrm{H}, \mathrm{d}, J=8.7 \mathrm{~Hz}$ uncomplexed $\mathrm{Ar}-\mathrm{H}), 7.01(3 \mathrm{H}, \mathrm{s}$, uncomplexed $\mathrm{Ar}-\mathrm{H}), 6.22(24 \mathrm{H}, \mathrm{d}, J=7.2 \mathrm{~Hz}$, complexed Ar-H), $5.20(30 \mathrm{H}, \mathrm{s}, \mathrm{Cp}-\mathrm{H}), 2.37\left(6 \mathrm{H}, \mathrm{s}, \mathrm{CH}_{2}\right), 2.11\left(6 \mathrm{H}, \mathrm{s}, \mathrm{CH}_{2}\right), 2.01\left(18 \mathrm{H}, \mathrm{s}, \mathrm{CH}_{3}\right), 1.65$ $\left(9 \mathrm{H}, \mathrm{s}, \mathrm{CH}_{3}\right) .{ }^{13} \mathrm{C}$ NMR $\delta_{\mathrm{c}}\left(75 \mathrm{MHz}\right.$; DMSO- $\left.d_{6}\right): 169.26,152.62(\mathrm{CO}), 148.78,144.53,138.46,131.74$, and 130.68 (quat-C), 130.069, 122.69, 122.08, 121.67, 120.76, and 100.90 (uncomplexed Ar-C), 78.69 (Cp-C), 76.01 and 75.05 (complexed $\mathrm{Ar}-\mathrm{C}$ ), 32.42 and $30.65\left(\mathrm{CH}_{2}-\mathrm{C}\right), 27.87$ and $25.13\left(\mathrm{CH}_{3}-\mathrm{C}\right)$. The elemental

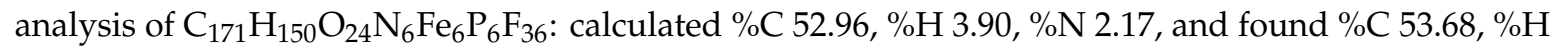
4.13 , and $\% \mathrm{~N} 2.47$. 


\subsubsection{Hydroxyl-Terminal Dendrimer (First-Generation D3)}

Dendrimer D3 was synthesized from dendrimer D1 (0.20 g, $0.06 \mathrm{mmol})$, 4-hydroxybenzyl alcohol $3(0.05 \mathrm{~g}, 0.30 \mathrm{mmol})$, and $\mathrm{K}_{2} \mathrm{CO}_{3}(0.26 \mathrm{~g}, 1.80 \mathrm{mmol})$ in $7 \mathrm{~mL}$ of DMF through nucleophilic substitution reaction. The reaction was left to stir at room temperature for three days after flushing with nitrogen for $1 \mathrm{~h}$. Subsequently, the reaction mixture was poured into $100 \mathrm{~mL}$ of $10 \% \mathrm{HCl}$ and $\mathrm{NH}_{4} \mathrm{PF}_{6}$ $(0.02 \mathrm{~g}, 0.24 \mathrm{mmol})$ was added for complete precipitation. The product was filtered and dried under vacuum. The resulting yellow solid was collected by suction filtration and dried under vacuum at room temperature.

Molecular weight $3716 \mathrm{~g} / \mathrm{mol}$ and yield 66\%. ATR-FTIR; $v_{\max } / \mathrm{cm}^{-1}: 3338(\mathrm{OH}), 2956(\mathrm{Ar}-\mathrm{C}), 2913$ (Cp-C), 1714 (CO), 1243 (C-O-C). ${ }^{1} \mathrm{H}$ NMR data $\left.\delta_{\mathrm{H}}(300 \mathrm{MHz} \text {; DMSO-d })_{6}\right): 7.48(12 \mathrm{H}, \mathrm{d}, J=8.4 \mathrm{~Hz}$, uncomplexed Ar-H), 7.37-7.23 (36H, m, uncomplexed Ar-H), 7.04 (3H, s, uncomplexed Ar-H), 6.25 $(24 \mathrm{H}, \mathrm{d}, J=6.0 \mathrm{~Hz}$, complexed Ar-H), $5.32(6 \mathrm{H}, \mathrm{d}, J=5.4 \mathrm{~Hz}, \mathrm{OH}), 5.22(30 \mathrm{H}, \mathrm{s}, \mathrm{Cp}-\mathrm{H}), 4.55(12 \mathrm{H}$, $\left.\mathrm{d}, J=6.3 \mathrm{~Hz}, \mathrm{CH}_{2}\right), 2.40\left(6 \mathrm{H}, \mathrm{s}, \mathrm{CH}_{2}\right), 2.12\left(6 \mathrm{H}, \mathrm{s}, \mathrm{CH}_{2}\right), 1.66\left(9 \mathrm{H}, \mathrm{s}, \mathrm{CH}_{3}\right) .{ }^{13} \mathrm{C} \mathrm{NMR} \delta_{\mathrm{c}}(75 \mathrm{MHz}$; DMSO- $d_{6}$ ): 174 (CO), 162.04, 159.62, 156.48, 153.21, 145.67, 140.48, and 133.85 (quat-C), 130.09, 129.97, 129.83, 129.57, 127.98, 121.21, and 120.75 (uncomplexed Ar-C), 78.83 (Cp-C), 74.85 and 74.48 (complexed Ar-C), 45.06, 26.33, and $25.99\left(\mathrm{CH}_{2}-\mathrm{C}\right), 30.40\left(\mathrm{CH}_{3}-\mathrm{C}\right)$. The elemental analysis of $\mathrm{C}_{165} \mathrm{H}_{144} \mathrm{O}_{24} \mathrm{Fe}_{6} \mathrm{P}_{6} \mathrm{~F}_{36}$ : calculated $\% \mathrm{C} 53.33, \% \mathrm{H} \mathrm{3.98}$, and found $\% \mathrm{C} 53.86$, and $\% \mathrm{H} 4.20$.

\subsubsection{Chloro-Terminal Dendrimer (Second-Generation D4)}

In a procedure analogous to the synthesis of D1, dendrimer D4 was synthesized from dendrimer D3 (0.16 g, $0.29 \mathrm{mmol})$, bimetallic organoiron complex $1\left(0.27 \mathrm{~g}, 1.50 \times 10^{4} \mathrm{mmol}\right)$, DMAP (0.06 g, $0.50 \mathrm{mmol})$, and DCC $(0.05 \mathrm{~g}, 0.25 \mathrm{mmol})$ in $7 \mathrm{~mL}$ DMF. The resulting yellow solid was collected by suction filtration and dried under vacuum at room temperature.

Molecular weight $9843 \mathrm{~g} / \mathrm{mol}$ and yield 62\%. ATR-FTIR; $v_{\max } / \mathrm{cm}^{-1}: 3002$ (Ar-C), 2935 (Cp-C), 1721 (CO), 1230 (C-O-C). ${ }^{1} \mathrm{H}$ NMR data $\delta_{\mathrm{H}}\left(300 \mathrm{MHz}\right.$; DMSO- $\left.d_{6}\right): 7.37(48 \mathrm{H}, \mathrm{t}, J=8.5 \mathrm{~Hz}$, uncomplexed Ar-H), $7.29(48 \mathrm{H}, \mathrm{d}, J=8.7 \mathrm{~Hz}$, uncomplexed Ar-H), $7.02(3 \mathrm{H}, \mathrm{s}$, uncomplexed Ar-H), $6.82(24 \mathrm{H}, \mathrm{d}$, $J=6.0 \mathrm{~Hz}$, complexed Ar-H), $6.43(24 \mathrm{H}, \mathrm{d}, J=6.0 \mathrm{~Hz}$, complexed Ar-H), $6.26(24 \mathrm{H}, \mathrm{d}, J=6.0 \mathrm{~Hz}$, complexed Ar-H), $5.28(60 \mathrm{H}, \mathrm{s}, \mathrm{Cp}-\mathrm{H}), 5.22(30 \mathrm{H}, \mathrm{s}, \mathrm{Cp}-\mathrm{H}), 4.55\left(12 \mathrm{H}, \mathrm{d}, J=5.4 \mathrm{~Hz}, \mathrm{CH}_{2}\right), 2.41(18 \mathrm{H}$, $\left.\mathrm{s}, \mathrm{CH}_{2}\right), 2.09\left(18 \mathrm{H}, \mathrm{s}, \mathrm{CH}_{2}\right), 1.68\left(18 \mathrm{H}, \mathrm{s}, \mathrm{CH}_{3}\right) 1.62\left(9 \mathrm{H}, \mathrm{s}, \mathrm{CH}_{3}\right) .{ }^{13} \mathrm{C}$ NMR $\delta_{\mathrm{c}}\left(75 \mathrm{MHz} ; \mathrm{DMSO}-d_{6}\right)$ : 173.97 and 171.32 (CO), 152, 146.77, 132.85, and 103.25 (quat-C), 133.63, 132.95, 131.76, 131.53, 129.46, $128.84,128.20,126.18,119.77,119.49,117.99$, and 103.25 (uncomplexed Ar-C), 78.95 and $77.44(\mathrm{Cp}-\mathrm{C})$, 86.43 and 74.71 (complexed $\mathrm{Ar}-\mathrm{C}$ ), 61.73, 52.14, and $24.91\left(\mathrm{CH}_{2}-\mathrm{C}\right), 31.14$ and $24.91\left(\mathrm{CH}_{3}-\mathrm{C}\right)$. The elemental analysis of $\mathrm{C}_{399} \mathrm{H}_{336} \mathrm{O}_{42} \mathrm{Cl}_{12} \mathrm{Fe}_{18} \mathrm{P}_{18} \mathrm{~F}_{108}$ : calculated \%C 48.69, \%H 3.44, and found \%C 49.15, and \%H 3.66 .

\subsubsection{Paracetamol-Terminal Dendrimer (Second-Generation D5)}

In a procedure analogous to the synthesis of D2, dendrimer D5 was synthesized from dendrimer D4 (0.20 g, $0.02 \mathrm{mmol})$, acetaminophen 2 (0.03 g, $0.24 \mathrm{mmol})$, and $\mathrm{K}_{2} \mathrm{CO}_{3}(0.17 \mathrm{~g}, 1.20 \mathrm{mmol})$, in $7 \mathrm{~mL}$ DMF. The product was a yellow powder.

Molecular weight 11,219 g/mol and yield 53\%. ATR-FTIR; $v_{\max } / \mathrm{cm}^{-1}: 3401(\mathrm{NH}), 2877(\mathrm{Ar}-\mathrm{C})$, $2823(\mathrm{Cp}-\mathrm{C}), 1703$ (CO), $1223(\mathrm{C}-\mathrm{O}-\mathrm{C}) .{ }^{1} \mathrm{H}$ NMR data $\delta_{\mathrm{H}}\left(300 \mathrm{MHz} ; \mathrm{DMSO}-d_{6}\right): 10.13(12 \mathrm{H}, \mathrm{s}, \mathrm{NH})$, $7.75(24 \mathrm{H}, \mathrm{d}, J=7.2 \mathrm{~Hz}$, uncomplexed Ar-H), $7.34(60 \mathrm{H}, \mathrm{d}, J=7.2 \mathrm{~Hz}$, uncomplexed Ar-H), 7.25 (60H, d, $J=9.0 \mathrm{~Hz}$, uncomplexed Ar-H), $7.00(3 \mathrm{H}, \mathrm{s}$, uncomplexed Ar-H), $6.25(72 \mathrm{H}, \mathrm{d}, J=6.6 \mathrm{~Hz}$, complexed $\mathrm{Ar}-\mathrm{H}), 5.22(90 \mathrm{H}, \mathrm{s}, \mathrm{Cp}-\mathrm{H}), 4.56\left(12 \mathrm{H}, \mathrm{d}, J=6 \mathrm{~Hz}, \mathrm{CH}_{2}\right), 2.41\left(18 \mathrm{H}, \mathrm{s}, \mathrm{CH}_{2}\right), 2.03\left(18 \mathrm{H}, \mathrm{s}, \mathrm{CH}_{2}\right), 1.67(36 \mathrm{H}$, $\left.\mathrm{s}, \mathrm{CH}_{3}\right), 1.65\left(18 \mathrm{H}, \mathrm{s}, \mathrm{CH}_{3}\right), 1.61\left(9 \mathrm{H}, \mathrm{s}, \mathrm{CH}_{3}\right) .{ }^{13} \mathrm{C} \mathrm{NMR} \delta_{\mathrm{c}}\left(75 \mathrm{MHz} ; \mathrm{DMSO}-d_{6}\right): 174.48$ and $168.44(\mathrm{CO})$, 151.76, 147.98, 146.18, 140.81, 137.69, 130.87, and 129.19 (quat-C), 129.19, 128.65, 121.21, 120.85, 120.37, and 119,92 (uncomplexed Ar-C), 77.91 (Cp-C), 76.32 and 74.24 (complexed Ar-C),62.18, 33.34, 31.63, and $24.46\left(\mathrm{CH}_{2}-\mathrm{C}\right), 25.39$ and $24.01\left(\mathrm{CH}_{3}-\mathrm{C}\right)$. The elemental analysis of $\mathrm{C}_{495} \mathrm{H}_{432} \mathrm{O}_{24} \mathrm{~N}_{12} \mathrm{Fe}_{18} \mathrm{P}_{18} \mathrm{~F}_{108}$ : calculated \%C 52.99, \%H 3.88, \%N 1.50, and found \%C 53.51, \%H 4.19, and \%N 1.62. 


\subsubsection{Hydroxyl-Terminal Dendrimer (Second-Generation D6)}

In a procedure analogous to the synthesis of D3, dendrimer D6 was synthesized from dendrimer D4 (0.20 g, $0.02 \mathrm{mmol})$, 4-hydroxybenzyl alcohol 3 (0.03 g, $0.26 \mathrm{mmol})$, and $\mathrm{K}_{2} \mathrm{CO}_{3}(0.18 \mathrm{~g}, 1.30 \mathrm{mmol})$, in $7 \mathrm{~mL}$ DMF.

Molecular weight 10,895 g/mol and yield 52\%, yellow powder. ATR-FTIR; $v_{\max } / \mathrm{cm}^{-1}: 3334(\mathrm{OH})$, 2944 (Ar-C), 2962 (Cp-C), 1694 (CO), 1213 (C-O-C). ${ }^{1} \mathrm{H}$ NMR data $\delta_{\mathrm{H}}\left(300 \mathrm{MHz}\right.$; DMSO-d $\left.d_{6}\right): 7.48$ (36H, $\mathrm{d}, J=8.1 \mathrm{~Hz}$, uncomplexed $\mathrm{Ar}-\mathrm{H}), 7.32-7.21(108 \mathrm{H}, \mathrm{m}$, uncomplexed $\mathrm{Ar}-\mathrm{H}), 7.01(3 \mathrm{H}, \mathrm{s}$, uncomplexed Ar-H), $6.22(72 \mathrm{H}$, s, complexed Ar-H), $5.33(12 \mathrm{H}, \mathrm{d}, J=5.4 \mathrm{~Hz}, \mathrm{OH}), 5.20(90 \mathrm{H}, \mathrm{s}, \mathrm{Cp}-\mathrm{H}), 4.53(36 \mathrm{H}, \mathrm{d}$, $\left.J=5.4 \mathrm{~Hz}, \mathrm{CH}_{2}\right), 2.38\left(18 \mathrm{H}, \mathrm{s}, \mathrm{CH}_{2}\right), 2.04\left(18 \mathrm{H}, \mathrm{s}, \mathrm{CH}_{2}\right), 1.64\left(9 \mathrm{H}, \mathrm{s}, \mathrm{CH}_{3}\right), 1.59\left(18 \mathrm{H}, \mathrm{s}, \mathrm{CH}_{3}\right) .{ }^{13} \mathrm{C} \mathrm{NMR}$ $\delta_{\mathrm{c}}\left(75 \mathrm{MHz}\right.$; DMSO- $\left.d_{6}\right): 174.11,172.22$, and $162.04(\mathrm{CO}), 154.084,152.63,141.65,140.75,140.39,140.10$, 139.52, 138.65, and 133.04 (quat-C), 131.32, 130.91, 130.30, 130.05, 129.97, 129.81, 129.54, 129.45, 129.05, $128.08,127.96,121.23,120.78,118.87$, and 118.41 (uncomplexed $\mathrm{Ar}-\mathrm{C}), 78.84(\mathrm{Cp}-\mathrm{C}), 75.97$ and 75.48 (complexed $\mathrm{Ar}-\mathrm{C}), 65.79,63.05,43.89,26.27$, and $25.27\left(\mathrm{CH}_{2}-\mathrm{C}\right), 30.42,23.03$, and $19.33\left(\mathrm{CH}_{3}-\mathrm{C}\right)$. The elemental analysis of $\mathrm{C}_{483} \mathrm{H}_{420} \mathrm{O}_{66} \mathrm{Fe}_{18} \mathrm{P}_{18} \mathrm{~F}_{108}$ : calculated \%C 53.25, \%H 3.89, and found \%C 53.71, and \% 4.06.

\subsubsection{Choro-Terminal Dendrimer (Third-Generation D7)}

In a procedure analogous to the synthesis of D1, dendrimer D7 was synthesized from dendrimer D6 $(0.10 \mathrm{~g}, 9.20 \mu \mathrm{mol})$, bimetallic organoiron complex $1(0.12 \mathrm{~g}, 12 \mu \mathrm{mol})$, DMAP $(0.03 \mathrm{~g}, 18.40 \mu \mathrm{mol})$, and DCC $(0.03 \mathrm{~g}, 9.20 \mu \mathrm{mol})$ in $7 \mathrm{~mL}$ DMF. The resulting yellow powder was collected by suction filtration and dried under vacuum at room temperature.

Molecular weight 23,149 g/mol and yield 44\%. ATR-FTIR; $v_{\max } / \mathrm{cm}^{-1}: 3021$ (Ar-C), 2889 (Cp-C), $1692(\mathrm{CO}), 1237(\mathrm{C}-\mathrm{O}-\mathrm{C}) .{ }^{1} \mathrm{H}$ NMR data $\delta_{\mathrm{H}}\left(300 \mathrm{MHz} ; \mathrm{DMSO}-d_{6}\right): 7.48(24 \mathrm{H}, \mathrm{d}, J=8.4 \mathrm{~Hz}$, uncomplexed Ar-H), $7.32(96 \mathrm{H}$, s, uncomplexed Ar-H), $7.29(96 \mathrm{H}, \mathrm{d}, J=8.7 \mathrm{~Hz}$, uncomplexed Ar-H), $7.02(27 \mathrm{H}, \mathrm{s}$, uncomplexed Ar-H), $6.81(48 \mathrm{H}, \mathrm{d}, J=6.6 \mathrm{~Hz}$, complexed $\mathrm{Ar}-\mathrm{H}), 6.40(48 \mathrm{H}$, s, complexed $\mathrm{Ar}-\mathrm{H}), 6.26$ $\left(72 \mathrm{H}, \mathrm{d}, J=7.8 \mathrm{~Hz}\right.$, complexed Ar-H), $5.28(120 \mathrm{H}, \mathrm{s}, \mathrm{Cp}-\mathrm{H}), 5.22(90 \mathrm{H}, \mathrm{s}, \mathrm{Cp}-\mathrm{H}), 4.55\left(36 \mathrm{H}, \mathrm{s}, \mathrm{CH}_{2}\right)$, $2.39\left(42 \mathrm{H}, \mathrm{s}, \mathrm{CH}_{2}\right), 2.07\left(42 \mathrm{H}, \mathrm{s}, \mathrm{CH}_{2}\right), 1.64\left(63 \mathrm{H}, \mathrm{br}-\mathrm{s}, \mathrm{CH}_{3}\right) .{ }^{13} \mathrm{C}$ NMR $\delta_{\mathrm{c}}\left(75 \mathrm{MHz} ; \mathrm{DMSO}-d_{6}\right): 175.26$, 173.59, and 170.21 (CO), 154.28, 152.65, 152.03, 147.27, 147.06, 141.64 133.00, 131.40, and 104.53 (quat-C), 130.82, 130.189, 121.35, 121.161, 121.01, and 120.78 (uncomplexed Ar-C), 80.19 and 78.81 (Cp-C), 87.69, 77.32, and 76.05 (complexed Ar-C), 65.95, 63.14, 45.97, 34.27, and $31.18\left(\mathrm{CH}_{2}-\mathrm{C}\right), 36.65,31.68$, and $27.76\left(\mathrm{CH}_{3}-\mathrm{C}\right)$. The elemental analysis of $\mathrm{C}_{951} \mathrm{H}_{804} \mathrm{O}_{42} \mathrm{Cl}_{24} \mathrm{Fe}_{42} \mathrm{P}_{42} \mathrm{~F}_{252}$ : Calculated \%C 49.34, \% 3.50 , and found $\% \mathrm{C} 50.23$ and $\% \mathrm{H} 3.69$.

\subsubsection{Paracetamol-Terminal Dendrimer (Third-Generation D8)}

In a procedure analogous to the synthesis of D2, dendrimer D8 was synthesized from dendrimer D7 $(0.10 \mathrm{~g}, 4.18 \mu \mathrm{mol})$, acetaminophen $2(0.02 \mathrm{~g}, 108.00 \mu \mathrm{mol})$, and $\mathrm{K}_{2} \mathrm{CO}_{3}(0.10 \mathrm{~g}, 0.50 \mathrm{mmol})$, in $7 \mathrm{~mL}$ DMF.

Molecular weight $25,902 \mathrm{~g} / \mathrm{mol}$ and yield $61 \%$ as yellow powder. ATR-FTIR; $v_{\max } / \mathrm{cm}^{-1}: 3437(\mathrm{NH})$, 2932 (Ar-C), 2823 (Cp-C), 1708 (CO), $1217(\mathrm{C}-\mathrm{O}-\mathrm{C}) .{ }^{1} \mathrm{H}$ NMR data $\delta_{\mathrm{H}}\left(300 \mathrm{MHz} ; \mathrm{DMSO}-d_{6}\right): 10.13$ $(24 \mathrm{H}, \mathrm{s}, \mathrm{NH}), 7.76(36 \mathrm{H}, \mathrm{d}, J=8.7 \mathrm{~Hz}$, uncomplexed $\mathrm{Ar}-\mathrm{H}), 7.34(168 \mathrm{H}$, s, uncomplexed Ar-H), 7.25 $(84 \mathrm{H}, \mathrm{d}, J=9.3 \mathrm{~Hz}$, uncomplexed $\mathrm{Ar}-\mathrm{H}), 7.04(51 \mathrm{H}$, s, uncomplexed $\mathrm{Ar}-\mathrm{H}), 6.25(168 \mathrm{H}, \mathrm{d}, J=7.2 \mathrm{~Hz}$, complexed Ar-H), $5.22(210 \mathrm{H}, \mathrm{s}, \mathrm{Cp}-\mathrm{H}), 5.06\left(24 \mathrm{H}, \mathrm{s}, \mathrm{CH}_{2}\right), 4.55\left(12 \mathrm{H}, \mathrm{s}, \mathrm{CH}_{2}\right), 2.41\left(42 \mathrm{H}, \mathrm{s}, \mathrm{CH}_{2}\right), 2.03$ $\left(42 \mathrm{H}, \mathrm{s}, \mathrm{CH}_{2}\right), 1.65\left(135 \mathrm{H}, \mathrm{s}, \mathrm{CH}_{3}\right) .{ }^{13} \mathrm{C}$ NMR $\delta_{\mathrm{c}}\left(75 \mathrm{MHz}\right.$; DMSO- $\left.d_{6}\right): 175,173.62,171.65$, and 169.32 (CO), 153.50, 148.99, 138.51, 131.74, 131.33, 130.65, and 129.46 (quat-C), 130.04, 122.04, 121.707, 121.35, 121.18, 120.72, and 119,82 (uncomplexed Ar-C), $78.69(\mathrm{Cp}-\mathrm{C}$ ), 76.04 and 75.03 (complexed Ar-C), 65.87, $63.02,45.78,34.25,30.84$, and $25.35\left(\mathrm{CH}_{2}-\mathrm{C}\right), 49.03,27.57$, and $24.80\left(\mathrm{CH}_{3}-\mathrm{C}\right)$. The elemental analysis of $\mathrm{C}_{1143} \mathrm{H}_{996} \mathrm{O}_{150} \mathrm{~N}_{24} \mathrm{Fe}_{42} \mathrm{P}_{42} \mathrm{~F}_{252}$ : calculated $\% \mathrm{C} 53.00, \% \mathrm{H} 3.88, \% \mathrm{~N} \mathrm{1.30}$, and found \%C 53.76, \%H 4.11, and $\% \mathrm{~N} 1.51$. 


\subsubsection{Hydroxyl-Terminal Dendrimer (Third-Generation D9)}

In a procedure analogous to the synthesis of D3, dendrimer D9 was synthesized from dendrimer D7 (0.10 g, $4.18 \mu \mathrm{mol})$, 4-hydroxybenzyl alcohol $3(0.01 \mathrm{~g}, 108.00 \mu \mathrm{mol})$, and $\mathrm{K}_{2} \mathrm{CO}_{3}(0.10 \mathrm{~g}, 0.50 \mathrm{mmol})$, in $7 \mathrm{~mL}$ DMF. The product was a yellow powder.

Molecular weight 25,254 g/mol and yield 58\%. ATR-FTIR; $v_{\max } / \mathrm{cm}^{-1}: 3321(\mathrm{OH}), 2873(\mathrm{Ar}-\mathrm{C}), 2897$ $(\mathrm{Cp}-\mathrm{C}), 1722(\mathrm{CO}), 1221(\mathrm{C}-\mathrm{O}-\mathrm{C}) .{ }^{1} \mathrm{H}$ NMR data $\delta_{\mathrm{H}}\left(300 \mathrm{MHz}\right.$; DMSO- $\left.d_{6}\right): 7.47(168 \mathrm{H}, \mathrm{d}, J=7.2 \mathrm{~Hz}$, uncomplexed Ar-H), $7.26(84 \mathrm{H}, \mathrm{m}$, uncomplexed $\mathrm{Ar}-\mathrm{H}), 7.00(87 \mathrm{H}, \mathrm{s}$, uncomplexed $\mathrm{Ar}-\mathrm{H}), 6.26(168 \mathrm{H}$, s, complexed Ar-H), $5.29(24 \mathrm{H}, \mathrm{s}, \mathrm{OH}), 5.20(210 \mathrm{H}, \mathrm{s}, \mathrm{Cp}-\mathrm{H}), 4.53\left(48 \mathrm{H}, \mathrm{s}, \mathrm{CH}_{2}\right), 2.36\left(36 \mathrm{H}, \mathrm{s}, \mathrm{CH}_{2}\right), 2.16$ $\left(42 \mathrm{H}, \mathrm{s}, \mathrm{CH}_{2}\right), 2.05\left(42 \mathrm{H}, \mathrm{s}, \mathrm{CH}_{2}\right), 1.88\left(9 \mathrm{H}, \mathrm{s}, \mathrm{CH}_{3}\right), 1.63\left(18 \mathrm{H}, \mathrm{s}, \mathrm{CH}_{3}\right), 1.59\left(36 \mathrm{H}, \mathrm{s}, \mathrm{CH}_{3}\right) .{ }^{13} \mathrm{C} \mathrm{NMR}_{\mathrm{c}}$ (75 MHz; DMSO- $d_{6}$ ): 174.11, 172.22, and 162.04 (CO), 154.084, 152.63, 141.65, 140.75, 140.39, 140.10, 139.52, 138.65, and 133.04 (quat-C), 131.32, 130.91, 130.30, 130.05, 129.97, 129.81, 129.54, 129.45, 129.05, $128.08,127.96,121.23,120.78,118.87$, and 118.41 (uncomplexed $\mathrm{Ar}-\mathrm{C}), 78.84(\mathrm{Cp}-\mathrm{C}), 75.97$ and 75.48 (complexed Ar-C), 65.79, 63.05, 43.89, 26.27, and $25.27\left(\mathrm{CH}_{2}-\mathrm{C}\right), 36.12,31.42,27.03$, and $19.33\left(\mathrm{CH}_{3}-\mathrm{C}\right)$. The elemental analysis of $\mathrm{C}_{1119} \mathrm{H}_{972} \mathrm{O}_{150} \mathrm{Fe}_{42} \mathrm{P}_{42} \mathrm{~F}_{252}$ : calculated $\% \mathrm{C} 53.22, \% \mathrm{H} \mathrm{3.88}$, and found $\% \mathrm{C}$ 54.37 , and $\% \mathrm{H} 4.03$.

\subsubsection{Chloro Terminal Dendrimer (Fourth-Generation D10)}

In a procedure analogous to the synthesis of D1, dendrimer D10 was synthesized from dendrimer D9 $(0.20 \mathrm{~g}, 7.60 \mu \mathrm{mol})$, bimetallic organoiron complex $(0.19 \mathrm{~g}, 190.00 \mu \mathrm{mol})$, DMAP $(0.02 \mathrm{~g}, 380.00 \mu \mathrm{mol})$, and DCC $(0.03 \mathrm{~g}, 190.00 \mu \mathrm{mol})$ in $7 \mathrm{~mL}$ DMF. The resulting yellow solid was collected by suction filtration and dried under vacuum at room temperature.

Molecular weight 49,762 g/mol and yield 71\%. ATR-FTIR; $v_{\max } / \mathrm{cm}^{-1}: 2946$ (Ar-C), 2847 (Cp-C), $1722(\mathrm{CO}), 1221(\mathrm{C}-\mathrm{O}-\mathrm{C}) .{ }^{1} \mathrm{H}$ NMR data $\delta_{\mathrm{H}}\left(300 \mathrm{MHz}\right.$; DMSO- $\left.d_{6}\right): 7.49(264 \mathrm{H}, \mathrm{m}$, uncomplexed Ar-H), $7.37(267 \mathrm{H}, \mathrm{m}$, uncomplexed Ar-H), $6.82(96 \mathrm{H}, \mathrm{m}$, complexed Ar-H), $6.43(96 \mathrm{H}, \mathrm{m}$, complexed Ar-H), $6.27\left(168 \mathrm{H}, \mathrm{m}\right.$, complexed Ar-H), $5.28(240 \mathrm{H}, \mathrm{s}, \mathrm{Cp}-\mathrm{H}), 5.22(210 \mathrm{H}, \mathrm{s}, \mathrm{Cp}-\mathrm{H}), 5.12\left(21 \mathrm{H}, \mathrm{s}, \mathrm{CH}_{2}\right), 4.56$ $\left(42 \mathrm{H}, \mathrm{s}, \mathrm{CH}_{2}\right), 3.97\left(21 \mathrm{H}, \mathrm{s}, \mathrm{CH}_{2}\right), 2.41\left(90 \mathrm{H}, \mathrm{br}, \mathrm{s}, \mathrm{CH}_{2}\right), 2.34\left(90 \mathrm{H}, \mathrm{br}, \mathrm{s}, \mathrm{CH}_{2}\right), 1.68\left(108 \mathrm{H}, \mathrm{m}, \mathrm{CH}_{3}\right), 1.63$ $\left(27 \mathrm{H}, \mathrm{s}, \mathrm{CH}_{3}\right) .{ }^{13} \mathrm{C}$ NMR $\delta_{\mathrm{c}}\left(75 \mathrm{MHz}\right.$; DMSO- $\left.d_{6}\right)$ : 172.47 and 172.27 (CO), 154.32, 152.72, 151.99, 147.01, 141.70, 132.83, and 104.54 (quat-C), 131.34, 130.12, 129.51, 120.98, and 120.71 (uncomplexed Ar-C), 80.29 and $78.74(\mathrm{Cp}-\mathrm{C}), 87.71,77.30,75.97$, and 75.42 (complexed Ar-C), 65.84, 63.01, 32.50, 31.12, and $25.38\left(\mathrm{CH}_{2}-\mathrm{C}\right)$, 30.54 and $26.19\left(\mathrm{CH}_{3}-\mathrm{C}\right)$. The elemental analysis of $\mathrm{C}_{2055} \mathrm{H}_{1740} \mathrm{O}_{222} \mathrm{Cl}_{48} \mathrm{Fe}_{90} \mathrm{P}_{90} \mathrm{~F}_{540}$ : calculated \%C 49.60.35, \% 3.52 , and found \%C 50.09 and \%H 3.78 .

\subsubsection{Paracetamol-Terminal Dendrimer (Fourth-Generation D11)}

In the procedure analogous to the synthesis of D2, dendrimer D11 was synthesized from dendrimer D10 $(0.10 \mathrm{~g}, 1.90 \mu \mathrm{mol})$, acetaminophen $2(0.02 \mathrm{~g}, 96.00 \mu \mathrm{mol})$, and $\mathrm{K}_{2} \mathrm{CO}_{3}(0.10 \mathrm{~g}, 0.45 \mathrm{mmol})$, in $7 \mathrm{~mL}$ DMF. The product was a yellow powder.

Molecular weight 63,428 g/mol and yield 59\%. ATR-FTIR; $v_{\max } / \mathrm{cm}^{-1}: 3464(\mathrm{NH}), 2944(\mathrm{Ar}-\mathrm{C}), 2811$ $(\mathrm{Cp}-\mathrm{C}), 1716(\mathrm{CO}), 1231(\mathrm{C}-\mathrm{O}-\mathrm{C}) .{ }^{1} \mathrm{H}$ NMR data $\delta_{\mathrm{H}}\left(300 \mathrm{MHz}\right.$; DMSO- $\left.d_{6}\right): 10.13(48 \mathrm{H}, \mathrm{s}, \mathrm{NH}), 7.76(96 \mathrm{H}$, $\mathrm{d}, J=8.7 \mathrm{~Hz}$, uncomplexed $\mathrm{Ar}-\mathrm{H}), 7.49(264 \mathrm{H}, \mathrm{m}$, uncomplexed $\mathrm{Ar}-\mathrm{H}), 7.37(363 \mathrm{H}, \mathrm{m}$, uncomplexed Ar-H), $6.27\left(360 \mathrm{H}, \mathrm{m}\right.$, complexed Ar-H), $5.22(450 \mathrm{H}, \mathrm{s}, \mathrm{Cp}-\mathrm{H}), 4.56\left(42 \mathrm{H}, \mathrm{s}, \mathrm{CH}_{2}\right), 3.97\left(42 \mathrm{H}, \mathrm{s}, \mathrm{CH}_{2}\right)$, $2.41\left(90 \mathrm{H}, \mathrm{br}, \mathrm{s}, \mathrm{CH}_{2}\right), 2.34\left(90 \mathrm{H}, \mathrm{br}, \mathrm{s}, \mathrm{CH}_{2}\right), 1.72\left(144 \mathrm{H}, \mathrm{s}, \mathrm{CH}_{3}\right), 1.65\left(135 \mathrm{H}, \mathrm{s}, \mathrm{CH}_{3}\right) .{ }^{13} \mathrm{C} \mathrm{NMR}_{\mathrm{c}}$ (75 MHz; DMSO- $\left.d_{6}\right): 175.31,173.44,171.21$ and 169.43 (CO), 152.70, 148.84, 146.87, 141.62, 138.45, $131.76,131.33,130.72$ and 129.21 (quat-C), 130.04, 122.04, 121.707, 121.35, 121.18, 120.72 and 119,82 (uncomplexed Ar-C), $78.74(\mathrm{Cp}-\mathrm{C}), 75.97$ and 75.05 (complexed $\mathrm{Ar}-\mathrm{C}$ ), 63.17, 45.75, 36.98, 32.42, 26.86 and $25.35\left(\mathrm{CH}_{2}-\mathrm{C}\right), 27.86$ and $24.75\left(\mathrm{CH}_{3}-\mathrm{C}\right)$. The elemental analysis of $\mathrm{C}_{2439} \mathrm{H}_{2124} \mathrm{O}_{318} \mathrm{~N}_{48} \mathrm{Fe}_{90} \mathrm{P}_{90} \mathrm{~F}_{540}$ : calculated \%C 53.00, \% $3.87, \% \mathrm{~N} 1.22$, and found \%C 53.67, \% $4.01, \% \mathrm{~N} 1.51$. 


\subsubsection{Hydroxyl-Terminal Dendrimer (Fourth-Generation D12)}

Similarly, the synthesis of D3, dendrimer D12 was synthesized from dendrimer D10 (0.10 g, $1.90 \mu \mathrm{mol})$, 4-hydroxybenzyl alcohol $3(0.01 \mathrm{~g}, 96.00 \mu \mathrm{mol})$, and $\mathrm{K}_{2} \mathrm{CO}_{3}(0.07 \mathrm{~g}, 2.30 \mathrm{mmol})$, in $7 \mathrm{~mL}$ DMF. The product was a yellow solid.

Molecular weight 53,971 g/mol and yield 51\%. ATR-FTIR; $v_{\max } / \mathrm{cm}^{-1}: 3324(\mathrm{OH}), 2972(\mathrm{Ar}-\mathrm{C})$, $2898(\mathrm{Cp}-\mathrm{C}), 1714$ (CO), $1222(\mathrm{C}-\mathrm{O}-\mathrm{C}) .{ }^{1} \mathrm{H}$ NMR data $\delta_{\mathrm{H}}\left(300 \mathrm{MHz} ; \mathrm{DMSO}-d_{6}\right): 7.49(96 \mathrm{H}, \mathrm{m}$, uncomplexed Ar-H), $7.47(264 \mathrm{H}, \mathrm{m}$, uncomplexed Ar-H), 7.37 (267H, m, uncomplexed Ar-H), 7.03 (96H, m, uncomplexed Ar-H), $6.26(360 \mathrm{H}, \mathrm{d}, J=6.0 \mathrm{~Hz}$, complexed Ar-H), $5.29(48 \mathrm{H}, \mathrm{s}, \mathrm{OH}), 5.22$ $(450 \mathrm{H}, \mathrm{s}, \mathrm{Cp}-\mathrm{H}), 5.12\left(21 \mathrm{H}, \mathrm{s}, \mathrm{CH}_{2}\right), 4.55\left(42 \mathrm{H}, \mathrm{s}, \mathrm{CH}_{2}\right), 3.97\left(21 \mathrm{H}, \mathrm{s}, \mathrm{CH}_{2}\right), 2.41\left(90 \mathrm{H}, \mathrm{br}, \mathrm{s}, \mathrm{CH}_{2}\right), 2.22$ $\left(96 \mathrm{H}\right.$, br s, $\left.\mathrm{CH}_{2}\right), 2.08\left(90 \mathrm{H}, \mathrm{br}, \mathrm{s}, \mathrm{CH}_{2}\right), 1.66\left(108 \mathrm{H}, \mathrm{m}, \mathrm{CH}_{3}\right), 1.62\left(27 \mathrm{H}, \mathrm{s}, \mathrm{CH}_{3}\right) .{ }^{13} \mathrm{C} \mathrm{NMR} \delta_{\mathrm{c}}(75 \mathrm{MHz}$; DMSO- $\left.d_{6}\right): 175.26,173.58$, and 163.19 (CO), 163.19, 152.67, 152,51, 146.51, 141.63, 131.41, and 130.75 (quat-C), 130.05, 129.47, 121.19, 120.78 and 119.33 (uncomplexed Ar-C), 78.80 (Cp-C), 76.03 and 75.46 (complexed Ar-C), 63.13, 45.92, 37.65, 32.49, 31.64, 30.63, and 25.14 $\left(\mathrm{CH}_{2}-\mathrm{C}\right), 37.04$ and $26.28\left(\mathrm{CH}_{3}-\mathrm{C}\right)$. The elemental analysis of $\mathrm{C}_{2391} \mathrm{H}_{2076} \mathrm{O}_{318} \mathrm{Fe}_{90} \mathrm{P}_{90} \mathrm{~F}_{540}$ : Calculated \%C 53.21, \% $\mathrm{H} .88$, and found \%C 52.83 and $\% \mathrm{H} 4.11$.

\section{Conclusions}

In summary, four generations of cationic, redox-active organometallic dendrimers were synthesized with three different end groups. The biologically active organoiron complex was used to synthesize the first paracetamol dendrimers with up to 90 redox-active units in the highest generation. All dendrimers were examined as antimicrobial agents against a broad spectrum of pathogenic microbes that included Gram-positive bacteria and Gram-negative bacteria. High levels of inhibition have been shown for the Gram-positive bacteria, while no activity was observed for the Gram-negative bacteria or C. albicans. The effectiveness of these antimicrobial agents against the Gram-positive bacteria were due to the organometallic dendritic scaffold and the terminal end groups. The effect on the Gram-positive bacteria may have occurred via two mechanisms: interaction with the cell membrane and the induction of oxidative stress on bacteria. The results suggested that both mechanisms participated in the antimicrobial activity of these dendrimers. Moreover, functionalization enhanced the antimicrobial impact on the dendrimers, with the secondary amine group-functionalized paracetamol dendrimers being more active than others. It is worth mentioning that increasing the number of generations of dendrimers profoundly influenced the activity. The best result has been recorded for the fourth-generation D11, which was attached to 48 paracetamol end groups and has 90 units of $\eta^{6}$-aryl- $\eta^{5}$-cyclopentadienyliron (II) complex. These macromolecules, functionalized with paracetamol moieties, obtained high potential activity against Gram-positive bacteria in addition to the central analgesic effect. In future work, we plan to create more bioactive dendrimers and test them against numerous types of infectious microbe as well as investigating them for potential use as anticancer agents.

Author Contributions: A.S.A.-E.-A., E.G.E.-G. and A.A.A. conceived and designed the experiments; E.G.E.-G. performed the experiments. All authors analyzed the data, wrote the paper, edited English language, and discussed the results and commented on the manuscript. All authors have read and agreed to the published version of the manuscript.

Funding: This research received no external funding.

Acknowledgments: Ebtehal G. El-Ghezlani would like to express her gratitude to the Faculty of Science, El-Mergib University, Khoms, Libya, for its support during her PhD.

Conflicts of Interest: The authors declare no conflict of interest. 


\section{References}

1. Shrivastava, S.R.; Shrivastava, P.S.; Ramasamy, J. Much more is expected from nations to counter antimicrobial resistance: World health organization. J. Res. Med. Sci. 2015, 20, 719-720. [CrossRef]

2. Swartjes, J.J.T.M.; Sharma, P.K.; Kooten, T.G. v.; van der Mei, H.C.; Mahmoudi, M.; Busscher, H.J.; Rochford, E.T.J. Current developments in antimicrobial surface coatings for biomedical applications. Curr. Med. Chem. 2015, 22, 2116-2129. [CrossRef]

3. Li, P.; Li, X.; Saravanan, R.; Li, C.M.; Leong, S.S.J. Antimicrobial macromolecules: Synthesis methods and future applications. RSC Adv. 2012, 22, 4031-4044. [CrossRef]

4. Muñoz-Bonilla, A.; Fernández-García, M. Polymeric materials with antimicrobial activity. Prog. Polym. Sci. 2012, 37, 281-339. [CrossRef]

5. Eby, D.M.; Luckarift, H.R.; Johnson, G.R. Hybrid antimicrobial enzyme and silver nanoparticle coatings for medical instruments. ACS Appl. Mater. Interfaces 2009, 1, 1553-1560. [CrossRef] [PubMed]

6. Kenawy, E.; Worley, S.; Broughton, R. The chemistry and applications of antimicrobial polymers: A state-of-the-art review. Biomacromolecules 2007, 8, 1359-1384. [CrossRef]

7. Lyu, Z.; Ding, L.; Huang, A.; Kao, C.; Peng, L. Poly (amidoamine) dendrimers: Covalent and supramolecular synthesis. Mater. Today Chem. 2019, 13, 34-48. [CrossRef]

8. Tianyou, C.; Zihao, W.; Zizheng, X.; Zushun, X.; Zheng, C. Synthesis and applications of dendrimer-based inorganic nanoparticles. Prog. Chem. 2020, 32, 249.

9. Roeven, E.; Scheres, L.; Smulders, M.M.; Zuilhof, H. Design, synthesis, and characterization of fully zwitterionic, functionalized dendrimers. ACS Omega 2019, 4, 3000-3011. [CrossRef]

10. England, R.M.; Hare, J.; Gunnarsson, A.; Parker, J.S.; Ashford, M.B. Synthesis and characterization of dendrimer-based polysarcosine star polymers: Well-defined, versatile platforms designed for drug delivery applications. Biomacromolecules 2020, 21, 3332-3341. [CrossRef]

11. Niu, Y.; Crooks, R.M. Dendrimer-encapsulated metal nanoparticles and their applications to catalysis. C. R. Chim. 2003, 6, 1049-1059. [CrossRef]

12. Crooks, R.M.; Zhao, M.; Sun, L.; Chechik, V.; Yeung, L.K. Dendrimer-encapsulated metal nanoparticles: Synthesis, characterization, and applications to catalysis. Acc. Chem. Res. 2001, 34, 181-190. [CrossRef] [PubMed]

13. Méry, D.; Astruc, D. Dendritic catalysis: Major concepts and recent progress. Coord. Chem. Rev. 2006, 250, 1965-1979. [CrossRef]

14. Astruc, D.; Chardac, F. Dendritic catalysts and dendrimers in catalysis. Chem. Rev. 2001, 101, $2991-3024$. [CrossRef] [PubMed]

15. Astruc, D.; Boisselier, E.; Ornelas, C. Dendrimers designed for functions: From physical, photophysical, and supramolecular properties to applications in sensing, catalysis, molecular electronics, photonics, and nanomedicine. Chem. Rev. 2010, 110, 1857-1959. [CrossRef]

16. Astruc, D. Electron-transfer processes in dendrimers and their implication in biology, catalysis, sensing and nanotechnology. Nat. Chem. 2012, 4, 255-267. [CrossRef]

17. Georgakilas, V.; Tiwari, J.N.; Kemp, K.C.; Perman, J.A.; Bourlinos, A.B.; Kim, K.S.; Zboril, R. Noncovalent functionalization of graphene and graphene oxide for energy materials, biosensing, catalytic, and biomedical applications. Chem. Rev. 2016, 116, 5464-5519. [CrossRef]

18. Albrecht, K.; Matsuoka, K.; Fujita, K.; Yamamoto, K. A dendrimer emitter doped in a dendrimer host: Efficient thermally activated delayed fluorescence OLEDs with fully-solution processed organic-layers. Mater. Chem Front. 2018, 2, 1097-1103. [CrossRef]

19. Hamai, S.; Hirayama, F. Actinometric determination of absolute fluorescence quantum yields. J. Phys. Chem. 1983, 87, 83-89. [CrossRef]

20. Abd-El-Aziz, A.S.; Abdelghani, A.A.; Wagner, B.D.; Pearson, J.K.; Awad, M.K. Design of blue fluorescence emitter star-shaped macromolecules based on pyrene and anthracene. Polymer 2016, 98, 210-228. [CrossRef]

21. Huang, G.; Ma, B.; Chen, J.; Peng, Q.; Zhang, G.; Fan, Q.; Zhang, D. Dendron-Containing tetraphenylethylene compounds: Dependence of fluorescence and photocyclization reactivity on the dendron generation. Chem. Eur. J. 2012, 18, 3886-3892. [CrossRef] [PubMed] 
22. Alsehli, M.; Al-Raqa, S.Y.; Kucukkaya, I.; Shipley, P.R.; Wagner, B.D.; Abd-El-Aziz, A.S. Synthesis and photophysical properties of a series of novel porphyrin dendrimers containing organoiron complexes. J. Inorg. Organomet. Polym. 2019, 29, 628-641. [CrossRef]

23. Chen, C.Z.; Beck-Tan, N.C.; Dhurjati, P.; van Dyk, T.K.; LaRossa, R.A.; Cooper, S.L. Quaternary ammonium functionalized poly (propylene imine) dendrimers as effective antimicrobials: Structure- activity studies. Biomacromolecules 2000, 1, 473-480. [CrossRef] [PubMed]

24. Balogh, L.; Swanson, D.R.; Tomalia, D.A.; Hagnauer, G.L.; McManus, A.T. Dendrimer-silver complexes and nanocomposites as antimicrobial agents. Nano Lett. 2001, 1, 18-21. [CrossRef]

25. García-Gallego, S.; Franci, G.; Falanga, A.; Gómez, R.; Folliero, V.; Galdiero, S.; De la Mata, F.J.; Galdiero, M. Function oriented molecular design: Dendrimers as novel antimicrobials. Molecules 2017, 22, 1581. [CrossRef] [PubMed]

26. Rabiee, N.; Ahmadvand, S.; Ahmadi, S.; Fatahi, Y.; Dinarvand, R.; Bagherzadeh, M.; Rabiee, M.; Tahriri, M.; Tayebi, L.; Hamblin, M.R. Carbosilane dendrimers: Drug and gene delivery applications. J. Drug Deliv. Sci. Technol. 2020, 59, 101879. [CrossRef]

27. Lyu, Z.; Ding, L.; Dhumal, D.; Ya-Ting Huang, A.; Kao, C.-L.; Peng, L. Poly(amidoamine) (PAMAM) dendrimers: Synthesis and biological applications. In Dendrimer Chemistry: Synthetic Approaches towards Complex Architectures; Malkoch, M., García-Gallego, S., Eds.; The Royal Society of Chemistry: London, UK, 2020; pp. 85-113.

28. Abd-El-Aziz, A.S.; Abdelghani, A.A.; Mishra, A.K. Optical and biological properties of metal-containing macromolecules. J. Inorg. Organomet. Polym. 2020, 30, 3-41. [CrossRef]

29. Abd-El-Aziz, A.S.; Agatemor, C. Emerging opportunities in the biomedical applications of dendrimers. J. Inorg. Organomet. Polym. 2018, 28, 369-382. [CrossRef]

30. Abd-El-Aziz, A.S.; Agatemor, C.; Etkin, N.; Bissessur, R. Tunable room-temperature soft ferromagnetism in magnetoceramics of organometallic dendrimers. J. Mater. Chem. 2017, 5, 2268-2281. [CrossRef]

31. Abd-El-Aziz, A.S.; Agatemor, C.; Etkin, N. Antimicrobial resistance challenged with metal-based antimicrobial macromolecules. Biomaterials 2017, 118, 27-50. [CrossRef]

32. Abd-El-Aziz, A.S.; Abdelghani, A.A.; Pearson, J.K.; Awad, M.K.; Overy, D.P.; Kerr, R.G. Design of piperazine organoiron macromolecules with antibacterial and anticancer activity. Macromol. Chem. Phys. 2016, 217, 987-996. [CrossRef]

33. Abd-El-Aziz, A.S.; Agatemor, C.; Etkin, N.; Overy, D.P.; Lanteigne, M.; McQuillan, K.; Kerr, R.G. Antimicrobial organometallic dendrimers with tunable activity against multidrug-resistant bacteria. Biomacromolecules 2015, 16, 3694-3703. [CrossRef] [PubMed]

34. Abd-El-Aziz, A.S.; Abdelghani, A.A.; El-Sadany, S.K.; Overy, D.P.; Kerr, R.G. Antimicrobial and anticancer activities of organoiron melamine dendrimers capped with piperazine moieties. Eur. Polym. 2016, 82, 307-323. [CrossRef]

35. Juris, A. 6 recent developments in photo-and redox-active dendrimers. Annu. Rep. Prog. Chem. Sect. C Phys. Chem. 2003, 99, 177-241. [CrossRef]

36. Wang, H.; Tang, W.; Wei, H.; Zhao, Y.; Hu, S.; Guan, Y.; Pan, W.; Xia, B.; Li, N.; Liu, F. Integrating dye-intercalated DNA dendrimers with electrospun nanofibers: A new fluorescent sensing platform for nucleic acids, proteins, and cells. J. Mater. Chem. B 2015, 3, 3541-3547. [CrossRef]

37. Astruc, D.; Hamon, J.R.; Althoff, G.; Roman, E.; Batail, P.; Michaud, P.; Mariot, J.P.; Varret, F.; Cozak, D. Design, stabilization, and efficiency of organometallic" electron reservoirs". 19-electron sandwiches. eta. 5-C5R5FeI-. eta. 6-C6R'6, a key class active in redox catalysis. J. Am. Chem Soc. 1979, 101, 5445-5447. [CrossRef]

38. Astruc, D. Electron-reservoir complexes and other redox-robust reagents: Functions and applications. New J. Chem. 2009, 33, 1191-1206. [CrossRef]

39. Cuadrado, I.; Morán, M.; Casado, C.M.; Alonso, B.; Losada, J. Organometallic dendrimers with transition metals. Coord. Chem. Rev. 1999, 193, 395-445. [CrossRef]

40. Abd-El-Aziz, A.S.; Strohm, E.A. Transition metal-containing macromolecules: En route to new functional materials. Polymer 2012, 53, 4879-4921. [CrossRef]

41. Abd-El-Aziz, A.S. Monomers, oligomers and polymers containing arenes with pendent transition metal moieties. Coord. Chem. Rev. 2002, 233, 177-191. [CrossRef] 
42. Astruc, D. Transition metal sandwiches as reservoirs of electrons, protons, hydrogen atoms and hydrides: Molecular activation and electronics. New J. Chem. 1992, 16, 305-328.

43. Abd-El-Aziz, A.S.; Agatemor, C.; Etkin, N.; Overy, D.P.; Kerr, R.G. Redox-active cationic organoiron complex: A promising lead structure for developing antimicrobial agents with activity against gram-positive pathogens including methicillin-resistant staphylococcus aureus and vancomycin-resistant enterococcus faecium. RSC Adv. 2015, 5, 86421-86427. [CrossRef]

44. Paramo, B.J.; Gancedo, S.Q.; Cuevas, M.; Camo, I.P.; Martin, J.A.; Cosmes, E.L. Paracetamol (acetaminophen) hypersensitivity. Ann. Allergy Asthma Immunol. 2000, 85, 508-511. [CrossRef]

45. Anderson, B.J. Paracetamol (acetaminophen): Mechanisms of action. Pediatr. Anesth. 2008, 18, 915-921. [CrossRef] [PubMed]

46. Vale, J.A.; Proudfoot, A.T. Paracetamol (acetaminophen) poisoning. Lancet 1995, 346, 547-552. [CrossRef]

47. Beaulieu, P. Non-opioid strategies for acute pain management. Can. J. Anaesth. 2007, 54, 481. [CrossRef]

48. Kehlet, H.; Dahl, J.B. The value of "multimodal" or" balanced analgesia" in postoperative pain treatment. Anesth. Analg. 1993, 77, 1048-1056. [CrossRef]

49. Maund, E.; McDaid, C.; Rice, S.; Wright, K.; Jenkins, B.; Woolacott, N. Paracetamol and selective and non-selective non-steroidal anti-inflammatory drugs for the reduction in morphine-related side-effects after major surgery: A systematic review. Br. J. Anaesth. 2011, 106, 292-297. [CrossRef]

50. Tan, T.Y.; Schug, S.A. Safety aspects of postoperative pain management. Anesth. Analg. 2006, 9, 45-53. [CrossRef]

51. Abd-El-Aziz, A.S.; Abdelghani, A.A.; Wagner, B.D.; Abdelrehim, E.M. Aggregation enhanced excimer emission (AEEE) with efficient blue emission based on pyrene dendrimers. Polym. Chem. 2016, 7, 3277-3299. [CrossRef]

52. Abd-El-Aziz, A.S.; Todd, E.K.; Afifi, T.H. Star-shaped polyaromatic ethers coordinated to redox-active cyclopentadienyliron moieties. Macromol. Rapid Commun. 2002, 23, 113-117. [CrossRef]

53. de Denus, C.R.; Baker, P.; Toner, J.; McKevitt, S.; Todd, E.K.; Abd-El-Aziz, A.S. Electrochemical investigations of oligomers and polymers containing ruthenium- and iron-arene complexes. Macromolecular 2003, 196, 113-123. [CrossRef]

54. Aranzaes, J.R.; Daniel, M.; Astruc, D. Metallocenes as references for the determination of redox potentials by cyclic voltammetry permethylated iron and cobalt sandwich complexes, inhibition by polyamine dendrimers, and the role of hydroxy-containing ferrocenes. Can. J. Chem. 2006, 84, 288-299. [CrossRef]

55. Aulenta, F.; Hayes, W.; Rannard, S. Dendrimers: A new class of nanoscopic containers and delivery devices. Eur. Polym. J. 2003, 39, 1741-1771. [CrossRef]

56. Abd-El-Aziz, A.S.; Agatemor, C.; Etkin, N.; Wagner, B.D. Photoinduced synthesis of Dual-Emissive Tetraphenylethene-Based dendrimers with tunable aggregates and solution states emissions. Macromol. Rapid Commun. 2016, 37, 1235-1241. [CrossRef] [PubMed]

57. Abd-El-Aziz, A.S.; Agatemor, C.; Etkin, N.; Bissessur, R.; Overy, D.P.; Lanteigne, M.; McQuillan, K.; Kerr, R.G. Quaternized and thiazole-functionalized free radical-generating organometallic dendrimers as antimicrobial platform against multidrug-resistant microorganisms. Macromol. Biosci. 2017, 17, 1700020. [CrossRef] [PubMed]

58. Serafim, M.S.; Lavorato, S.N.; Kronenberger, T.; Sousa, Y.V.; Oliveira, G.P.; Dos Santos, S.G.; Kroon, E.G.; Maltarollo, V.G.; Alves, R.J.; Mota, B.E. Antibacterial activity of synthetic 1, 3-bis (aryloxy) propan-2-amines against gram-positive bacteria. MicrobiologyOpen 2019, 8, e814. [CrossRef] [PubMed]

59. Miklasińska-Majdanik, M.; Kępa, M.; Wojtyczka, R.D.; Idzik, D.; Wąsik, T.J. Antibacterial activity of synthetic 1, 3-bis (aryloxy) propan-2-amines against gram-positive bacteria. Int. J. Environ. Res. Public Health 2018, 15, 2321.

60. Kayser, O.; Kolodziej, H. Antibacterial activity of simple coumarins: Structural requirements for biological activity. Zeitschrift für Naturforschung C 1999, 54, 169-174. [CrossRef]

61. Alcaraz, L.; Blanco, S.; Puig, O.; Tomas, F.; Ferretti, F. Antibacterial activity of flavonoids against methicillin-resistant staphylococcus aureus strains. J. Theor. Biol. 2000, 205, 231-240. [CrossRef]

62. Šmejkal, K.; Chudík, S.; Kloucek, P.; Marek, R.; Cvacka, J.; Urbanová, M.; Julínek, O.; Kokoška, L.; Šlapetová, T.; Holubová, P.; et al. Antibacterial C-geranylflavonoids from Paulownia tomentosa fruits. J. Nat. Prod. 2008, 71, 706-709. [CrossRef] 
63. Angiolini, L.; Cohen, B.; Douhal, A. Ultrafast dynamics of the antibiotic rifampicin in solution. Photochem. Photobiol. Sci. 2019, 18, 80-91. [CrossRef] [PubMed]

64. Wenzel, M.; Patra, M.; Senges, C.H.R.; Ott, I.; Stepanek, J.J.; Pinto, A.; Prochnow, P.; Vuong, C.; Langklotz, S.; Metzler-Nolte, N.; et al. Analysis of the mechanism of action of potent antibacterial hetero-tri-organometallic compounds: A structurally new class of antibiotics. ACS Chem. Biol. 2013, 8, 1442-1450. [CrossRef] [PubMed]

65. Deffert, C.; Cachat, J.; Krause, K. Phagocyte NADPH oxidase, chronic granulomatous disease and mycobacterial infections. Cell Microbiol. 2014, 16, 1168-1178. [CrossRef] [PubMed]

66. Rada, B.; Leto, T.L. Oxidative innate immune defenses by nox/duox family NADPH oxidases. Contrib. Microbiol. 2008, 15, 164-187. [CrossRef] [PubMed]

67. Kim, H.J.; Kim, C.H.; Ryu, J.H.; Kim, M.J.; Park, C.Y.; Lee, J.M.; Holtzman, M.J.; Yoon, J.H. Reactive oxygen species induce antiviral innate immune response through IFN- $\lambda$ regulation in human nasal epithelial cells. Am. J. Respir. Cell Mol. Biol. 2013, 49, 855-865. [CrossRef]

68. Abd-El-Aziz, A.S.; May, L.; Hurd, J.; Okasha, R. First ring-opening metathesis polymerization of norbornenes containing cationic iron moieties. J. Polym. Sci. A Polym. Chem. 2001, 39, 2716-2722. [CrossRef]

69. Neises, B.; Steglich, W. Simple method for the esterification of carboxylic acids. Angew. Chem. Int. Ed. 1978, 17, 522-524. [CrossRef]

70. Overy, D.P.; Berrue, F.; Correa, H.; Hanif, N.; Hay, K.; Lanteigne, M.; McQuillan, K.; Duffy, S.; Boland, P.; Jagannathan, R.; et al. Sea foam as a source of fungal inoculum for the isolation of biologically active natural products. Mycology. 2014, 5, 130-144. [CrossRef]

Sample Availability: Samples of the compounds are not available from the authors.

(C) 2020 by the authors. Licensee MDPI, Basel, Switzerland. This article is an open access article distributed under the terms and conditions of the Creative Commons Attribution (CC BY) license (http://creativecommons.org/licenses/by/4.0/). 